This version: 18 December 2015

\title{
Restructuring the European Business Enterprise: The EU Commission Recommendation on a New Approach to Business Failure and Insolvency
}

\author{
by
}

\author{
Horst Eidenmüller and Kristin van Zwieten*
}

\begin{abstract}
Two events are currently changing the landscape for business restructurings in the European Union: the "Restructuring Recommendation" (RR) of the European Commission, issued in 2014, and the 2015 recast of the European Insolvency Regulation (EIR). In this paper, we critically review the RR and put it into the context of the reform of the EIR. We find that the recast EIR and the RR do not dovetail perfectly-a restructuring proceeding as proposed by the RR would not necessarily be within the scope of the recast EIR; we also suggest that in any case the EIR is not optimally designed to facilitate restructurings, given its treatment of secured creditors. Regarding the regulatory approach pursued in the $R R$, the Commission rightly pushes towards harmonisation with respect to Member States' restructuring regimes - regulatory competition is not a sensible regulatory alternative in this area. However, we criticise both the methodology and scope of the harmonisation proposal of the RR: sketchy minimum harmonisation of restructuring rules leaves huge potential for residual diversity in Member States' restructuring laws, and the Commission's narrow focus on restructuring proceedings ignores several aspects of the complicated interaction between the Member States' formal insolvency laws and the restructuring mechanism proposed. Further, we disagree with the substantive recommendations for Member States' restructuring laws suggested by the RR: the proposed restructuring rules wrongly require financial difficulties or a likelihood of insolvency as an entry test for the recommended restructuring proceeding, and the process might be abused by sophisticated financial investors as a tool to enrich themselves at the expense of outside creditors and/or the debtor firm - it does not foresee the mandatory appointment of a supervisor, and it allows significant curtailments of creditor rights without sufficient safeguards in place. Instead, we propose an efficient debtor-in-possession (DIP) regime as an alternative that could be initiated regardless of a firm's solvency provided that it is economically viable and that the filing is not abusive.
\end{abstract}

\section{Table of Contents}

I. Introduction

II. The Restructuring Recommendation of the EU Commission

III. The Restructuring Recommendation and the Reform of the European Insolvency Regulation

IV. Evaluation of the Restructuring Recommendation

V. Summary and Outlook

\section{Introduction}

Laws on restructuring businesses that find themselves near or in financial distress are becoming ever more important - worldwide. ${ }^{1}$ The importance of these laws for critical economic factors

\footnotetext{
* Dr Horst Eidenmüller is the Freshfields Professor of Commercial Law at the University of Oxford, Professorial
} 
such as preserving going concern values and jobs, entrepreneurship, investment and growth is increasingly recognised. ${ }^{2}$ Out-of-court restructurings (workouts) exhibit efficiency advantages compared to those negotiated within a formal (state-supplied) restructuring procedure. However, they suffer from the well-known free rider problem, which renders them a fragile tool with only limited practical utility. ${ }^{3}$ State-supplied procedures can provide instruments to limit the opportunities for free riding and other forms of strategic behaviour in the negotiation of a restructuring.

One indicator of the attractiveness of some state-supplied restructuring procedures is 'restructuring migration', and migration-less restructuring arbitrage. Important German firms like Schefenacker and Deutsche Nickel, for example, moved their "centre of main interests" (COMI) to England and were restructured there later. ${ }^{4}$ The more recent Magyar Telecom ${ }^{5}$ case involved a COMI shift by a Dutch firm to England for the same purpose. Other German and Dutch firms have succeeded in using English restructuring procedures to restructure liabilities governed by English law without shifting their COMI to the UK, as in the Rodenstock ${ }^{6}$ and van Gansewinkel ${ }^{7}$ cases. These cases suggest that there is scope for a certain degree of regulatory competition in relation to the development of national laws on business restructurings within Europe. Clearly, such competition is likely to be more intense in relation to large established firms compared to SMEs or start-ups: forum shopping can be quite expensive. From a cost-benefit perspective, it might pay for the former class of firm, but usually not for the latter. ${ }^{8}$

Over the past seven years, many states have reformed their national restructuring laws, ${ }^{9}$ and others are presently in the process of doing so. Some of these reforms may have been at least partly fuelled by regulatory competition. For example, this appears to have been one of the factors that influenced the introduction of a new German law to improve the existing statutory restructuring framework (the "Gesetz zur weiteren Erleichterung der Sanierung von

1 See C. Paulus, 'Internationales Restrukturierungsrecht', 59 Recht der internationalen Wirtschaft (2013), 577.

2 J. Armour and D. Cumming, 'Bankruptcy Law and Enterpreneurship', 10 American Law and Economics Review (2008), 303; S.A. Davydenko and J. Franks, 'Do Bankruptcy Codes Matter? A Study of Defaults in France, Germany and the U.K.', 63 Journal of Finance (2008), 565; R. La Porta, F. Lopez-de-Silanes and A. Shleifer, 'Legal Determinants of External Finance', 52 The Journal of Finance (1997), 1131; R. La Porta, F. Lopez-de-Silanes, A. Shleifer and R.W. Vishny, 'Law and Finance', 106 The Journal of Political Economy (1998), 1113; R. La Porta, F. Lopez-de-Silanes, A. Shleifer and R. Vishny, 'Investor Protection and Corporate Valuation', 57 The Journal of Finance (2002), 1147.

3 H. Eidenmüller, Unternehmenssanierung zwischen Markt und Gesetz (Cologne, Otto Schmidt 1999), pp. 319 et seq., 346 et seq.

4 M.W. Buchenau, 'Schefenacker trickst Insolvenzrecht aus', Handelsblatt, 3 May 2007 [online]. Available at http://www.handelsblatt.com/unternehmen/industrie/umschuldung-zugestimmt-schefenacker-trickst-insolvenzrechtaus/2803488.html (accessed 19 August 2015).

5 Magyar Telecom BV [2013] EWHC 3800 (Ch), [2014] B.C.C. 448.

6 D. Fockenbrock, 'Pleitefälle wandern nach London aus', Handelsblatt, 27 June 2011 [online]. Available at http://www.handelsblatt.com/unternehmen/handel-dienstleister/insolvenzgeschaeft-pleitefaelle-wandern-nachlondon-aus/4326762.html (accessed 19 August 2015); see also Re Rodenstock GmbH [2011] EWHC 1104 (Ch), [2011] Bus. L.R. 1245.

7 Re van Gansewinkel Groep BV [2015] EWHC 2151 (Ch).

8 H. Eidenmüller, T. Frobenius and W. Prusko, 'Regulierungswettbewerb im Unternehmensinsolvenzrecht: Ergebnisse einer empirischen Untersuchung', 13 Neue Zeitschrift für Insolvenz- und Sanierungsrecht (2010), 545, 548 et seq.

9 See the summary of restructuring and insolvency reforms in World Bank, Business Reforms for Resolving Insolvency, 2014 [online]. Available at http://www.doingbusiness.org/reforms/overview/topic/resolving-insolvency (accessed 18 August 2015). 
Unternehmen (ESUG)", that entered into force on 1 March 2012). ${ }^{10}$ A second driver of this reform, and of restructuring law reforms elsewhere, has been the latest financial and economic crisis. In times of crisis, auctions are less attractive as a route to value preservation for financially distressed businesses. Hence, states are likely to seek to reform their restructuring laws at such times. $^{11}$

At the same time that many (European) states have been reforming their domestic restructuring laws, important changes have also been made to the European legal framework for cross-border restructurings. In 2012, the European Commission proposed amendments to the European Insolvency Regulation (EIR). ${ }^{12}$ This reform process was completed in June 2015 with the publication of a recast EIR that will be applicable in Member States from 26 June 2017. ${ }^{13}$ Whilst the "centre of main interests" (COMI) of a corporate debtor will be retained as the criterion for jurisdiction to open main insolvency proceedings ('main' proceedings being those endowed by the EIR with extraterritorial privileges, designed to ensure they extend to encompass assets and (unsecured) ${ }^{14}$ creditors wherever situated in the EU, with the exception of Denmark where the EIR does not apply), significant changes will be made to widen the Regulation's scope to encompass pre-insolvency and debtor-in-possession proceedings (Article 1 ),${ }^{15}$ to better secure the coordination of main proceedings with any rival local ('secondary') proceedings opened in other Member States in relation to the same debtor (Chapter III), ${ }^{16}$ and to enhance the coordination of insolvency proceedings relating to members of a group of companies (Chapter V). The extended scope of the recast EIR means that some national restructuring procedures previously excluded from the EIR will now fall within its scope, such that they are subject to its burdens (including its rules on jurisdiction to open proceedings, and on the coordination of proceedings), but eligible for its privileges - including those conferred on main proceedings to ensure EU-wide effectiveness.

${ }^{10}$ BGB1. 2011 I, pp. 2582 et seq.; and R. Bork, Rescuing Companies in England and Germany (Oxford, OUP 2012), Ch. 1 Part A, noting the financial crisis as a second driver of the reform.

11 See text to nn 70 et seq. below.

${ }^{12}$ European Commission, Report from the Commission to the European Parliament, the Council, and the European Economic and Social Committee on the application of Council Regulation (EC) No 1346/2000 of 29 May 2000 on insolvency proceedings, COM(2012) 743 final (12 December 2012); European Commission, Proposal for a Regulation of the European Parliament and of the Council amending Council Regulation (EC) No 1346/2000 on insolvency proceedings, $\operatorname{COM}(2012) 744$ final (12 December 2012). On the proposal see, for example, $\mathrm{H}$. Eidenmüller, 'A New Framework for Business Restructuring in Europe: The EU Commission's Proposals for a Reform of the European Insolvency Regulation and Beyond', 20 Maastricht Journal of European and Comparative Law (2013), 133; C. Thole, 'Die Reform der Europäischen Insolvenzverordnung', 22 Zeitschrift für Europäisches Privatrecht (2014), 39.

${ }^{13}$ Regulation (EU) 2015/848 of the European Parliament and of the Council of 20 May 2015 on insolvency proceedings (recast), OJ L141/19 (5 June 2015), Art. 92.

14 As to the exceptional position of secured creditors in relation to assets situated outside the Member State in which the proceedings were opened, see n 122 and text to n 136 et seq. below.

${ }^{15}$ However, pre-insolvency proceedings will be covered by the EIR only if they “ . . . are based on laws relating to insolvency ..." (Art. 1(1)). Hence, the English scheme of arrangement (SoA), which finds its legal basis in the Companies Act 2006 and "has not been designed exclusively for insolvency situations" (Recital 16), will not be within the ambit of the EIR (see also Annex A, which is intended to be determinative of scope (Art. 1(1), Art. 2(4), Recital 9) and in which the SoA does not appear). As a consequence, firms seeking to use the SoA will not be subject to the jurisdictional rules of the EIR, such that non-English firms will be able to use a SoA to restructure without moving their COMI to the UK (provided the domestic jurisdictional rules are satisfied). On the SoA as a cross-border restructuring tool see, for example, H. Eidenmüller and T. Frobenius, 'Die internationale Reichweite eines englischen Scheme of Arrangement', 65 Wertpapier-Mitteilungen (2011), 1210; J. Payne, 'Cross-Border Schemes of Arrangement and Forum Shopping', 14 EBOR (2013), 563. On the revised scope of the EIR, see Section III below.

${ }^{16}$ Note particularly new Articles 36, 38, 42 and 43 of the recast EIR 2015/848. 
What the "new" EIR does not require is the substantive harmonisation of Member States' insolvency or restructuring laws. Like the original EIR, the recast EIR is designed to work with the existing insolvency and restructuring procedures of Member States, and in particular to enhance the effectiveness of such procedures (provided they fall within the Regulation's scope) in cross-border cases. To date, the design of these procedures has for the most part been left to Member States to determine, along with the design of the institutional framework (courts; insolvency practitioners) within which they operate. At the present time, there is substantial divergence in both the design and operation of insolvency and restructuring procedures across Member States. Recent studies suggest that one consequence of this divergence is that some financially distressed debtors are better positioned than others to achieve a value preserving restructuring, as a consequence of their location or their superior ability to engage in restructuring migration (or migration-less restructuring arbitrage). ${ }^{17}$ If so, divergences in Member States' restructuring regimes imply different degrees of efficiency in the resolution of financial distress ex post; hence, they will influence the financing costs of businesses ex ante and, as a consequence, possibly distort investment decisions. ${ }^{18}$ Further, differences between Member States' substantive insolvency and restructuring regimes create obstacles for cross-border restructurings. Restructuring a multinational enterprise involves multiple jurisdictions whose laws have to be observed. The greater the differences between these laws, the greater the frictions and costs associated with the resolution of financial distress. The EIR was designed to ameliorate some of these costs, but it does not - not even in its recast form, with widened scope - apply to all forms of national restructuring procedures. ${ }^{19}$

Against this background, the European Parliament tasked the European Commission in 2012 with investigating the merits of harmonisation of some aspects of Member States' insolvency and/or restructuring regimes. ${ }^{20}$ The harmonisation agenda set out by the European Parliament was very broad, encompassing rules on when and how insolvency proceedings can be opened, the filing and verification of creditor claims to enable a distribution to be made in insolvency proceedings, the availability and scope of avoidance actions, the qualifications and work of insolvency practitioners, and the establishment, effects and content of restructuring plans. ${ }^{21}$ While the Commission expressed a certain sympathy for pursuing the path of harmonisation set out by the Parliament, ${ }^{22}$ it ultimately believed that the time was not ripe for such a step - at least in relation to the areas of insolvency law identified by the Parliament. In the Commission's view, more

\footnotetext{
${ }^{17}$ INSOL Europe (2010), Harmonisation of insolvency law at EU level, European Parliament, Directorate General for Internal Policies, Policy Department C: Citizens' Rights and Constitutional Affairs, Legal Affairs, PE 419.633, discussed in the text to nn 47 et seq. below; more recently, see M Carpus Carcea, D Ciriaci, C Cuerpo, D Lorenzani and P Pontuch, 'The Economic Impact of Rescue and Recovery Frameworks in the EU', European Commission Discussion Paper 004, September 2015, measuring the efficiency of Member States' restructuring frameworks using a new point-in-time index of formal ('law on the books') features.

${ }^{18}$ L.A. Bebchuk and A. Guzman, 'An Economic Analysis of Transnational Bankruptcies', 42 Journal of Law and Economics (1999), 775.

${ }^{19}$ See n 15 above and text to n 129 et seq below. Moreover, even where the EIR does apply, some aspects of its design may introduce new frictions in cross-border restructurings, particularly in relation to the position of secured creditors: see text to nn 136 et seq. below.

${ }^{20}$ European Parliament Committee on Legal Affairs, Report with recommendations to the Commission on insolvency proceedings in the context of EU company law (A7-0355/2011, 17 October 2011), and related resolution of the European Parliament of 15 November 2011 (2011/2006(INI)), discussed below in the text to nn 55 et seq.

${ }^{21}$ Resolution ibid, Annex Part 1.

${ }^{22}$ European Commission, Communication from the Commission to the European Parliament, the Council and the European Economic and Social Committee: A new European approach to business failure and insolvency (COM(2012) 724, 12 December 2012), discussed below in the text to nn 62 et seq.
} 
comparative analysis was needed in order to prepare the ground for harmonising these areas of the insolvency laws of the Member States. ${ }^{23}$

For the Commission, however, insolvency laws on the one hand and pre-insolvency restructuring rules on the other hand seem to be two different matters. In its view, both the desirability and feasibility of achieving some degree of harmonisation are apparently greater with respect to the latter. Only a little over a year after the Commission made the skeptical statement set out above, it published a recommendation ${ }^{24}$ that calls upon Member States to modernise their national restructuring laws so as to ensure the availability, in every Member State, of a procedure that facilitates "the efficient restructuring of viable enterprises in financial difficulty... thereby promoting entrepreneurship, investment and employment and contributing to reducing the obstacles to the smooth functioning of the internal market". ${ }^{25}$ The document contains a set of "minimum standards" for the design of such restructuring procedures. The Commission recently completed a review of Member State compliance with the Recommendation, and - having found partial compliance at best ${ }^{26}$ - has now announced (in the September 2015 Action Plan on Building a Capital Markets Union) its intention to propose a legislative initiative for harmonisation that will at least encompass the topics covered by the Recommendation. ${ }^{27}$

In this paper, we critically review the "Restructuring Recommendation" (RR) and put it into the context of the reform of the EIR. We find that the Commission rightly pushes towards harmonisation with respect to Member States' restructuring regimes - regulatory competition is not a sensible regulatory alternative in this area. However, we criticise both the methodology and scope of the RR. Further, we disagree with the substantive recommendations it makes for the design of Member States' restructuring laws. Instead, we propose an efficient debtor-inpossession (DIP) regime as an alternative that could be initiated regardless of a firm's solvency, provided that the firm is economically viable and the filing is not abusive. We start by detailing the RR (Section II) and placing it in the context of the EIR reform (Section III). In Section IV, we evaluate the RR with respect to its regulatory objective (harmonisation versus regulatory competition, Section IV 1), the subject and scope of the harmonisation proposals (Section IV 2) and the substantive recommendations made (Section IV 3). The article concludes with a summary of our main findings and an outlook on further reforms of restructuring laws in Europe (Section $\mathrm{V})$.

\footnotetext{
${ }^{23}$ European Commission, Impact Assessment accompanying the document Revision of Regulation (EC) No 1346/2000 on insolvency proceedings (Commission Staff Working Document), SWD(2012) 416 final, p. 44.

${ }^{24}$ European Commission, Recommendation of 12 March 2014 on a new approach to business failure and insolvency, C(2014) 1500 final. Recommendations are not binding on the Member States: Article 288 TFEU.

${ }^{25}$ C(2014) 1500 final, at No. 1. There is a second component of the Recommendation, not dealt with in this paper, concerning discharge periods for entrepreneurs in Member States' bankruptcy laws.

${ }^{26}$ Directorate-General Justice \& Consumers of the European Commission, "Evaluation of the implementation of the Recommendation of 12 March 2014 on a new approach to business failure and insolvency", 30 September 2015 (http://ec.europa.eu/justice/civil/commercial/insolvency/index_en.htm).

${ }^{27}$ Communication from the Commission to the European Parliament, The Council, The European Economic and Social Committee and the Committee of the Regions, "Action Plan on Building a Capital Markets Union", $\operatorname{COM}(2015)$ 468(final), Brussels, 30 September 2015, 25. It may be that other topics are also included within the scope of the proposal.
} 


\section{The Restructuring Recommendation of the EU Commission}

\section{The Subject of the Recommendation}

The primary subject of the Recommendation is restructuring, which the Commission defines as "changing the composition, conditions, or structure of assets and liabilities of debtors, or a combination of those elements, with the objective of enabling the continuation, in whole or in part, of the debtors' activity" (RR No. 5(b)). "Debtors" are defined as persons (natural or legal) that are in "financial difficulties when there is a likelihood of insolvency" (RR No. 5(a)). Read together, these provisions suggest that the Recommendation is chiefly concerned with restructuring the liabilities side of a debtor's balance sheet. Other provisions of the Recommendation make clear that it is further focused on the restructuring of the liabilities of debtors with a viable business (RR Nos. 1 and 16; see also Recitals 1, 5, 11, 12, 14): in other words, the paradigm case to which the Recommendation responds is one where a debtor is distressed (with all the costs that financial distress entails, including its impact on firm investment decisions $)^{28}$ but its underlying business is sound. A restructuring of debts - through their writedown or conversion to equity, or an adjustment of their terms, e.g. a maturity extension - is one route to the preservation of the value of this business: liberated from its debt burden, the debtor may return to its business activities and the pursuit of its investment opportunities. If debts are not restructured, then there is a risk of the debtor's entry into a formal insolvency procedure, and such a procedure will often be poorly suited to preserving the value of the business on a going concern basis. ${ }^{29}$ As such, if the business is to remain, at least in the short term, with the debtor (rather than being immediately sold to a third party), then an early 'pre-insolvency' restructuring may be the most sensible path to preservation of its value.

Such a restructuring cannot, however, be achieved by the debtor unilaterally. Unless creditors have agreed ex ante on a procedure to enable a prescribed majority of creditors to bind others to a restructuring plan,$^{30}$ any change in the scope or terms of the debtor's liabilities will require the consent of all creditors whose claims are to be affected. Negotiating with creditors to procure their consent ex post (i.e. after distress has arisen or is reasonably anticipated) may be difficult, particularly where creditors are numerous and there is some degree of heterogeneity in their rights or interests. ${ }^{31}$ Some creditors may hold out (that is, refuse to consent to any compromise) hoping that "the concessions that ensure the success of the restructuring will be borne by others", ${ }^{32}$ with the value of their uncompromised claims buoyed after the debtor emerges from the

\footnotetext{
${ }^{28}$ As modelled (with reference to different debt capital structures) by R. Gertner and D. Scharfstein, 'A theory of workouts and the effects of reorganization law', 46 Journal of Finance (1991), 1189.

${ }^{29}$ This may be so even where the procedure provides a mechanism for debt restructuring, if the procedure is too late to commence (with associated costs to investment opportunities), or is too slow or otherwise costly: see S.C. Gilson, 'Managing default: Some evidence on how firms choose between workouts and chapter 11' in Bhandari J.S. and Weiss L.A. (eds.), Corporate Bankruptcy: Economic and Legal Perspectives (Cambridge, CUP 1996), pp. 308 et seq.

${ }^{30}$ See $n 39$ below.

${ }^{31}$ See H. Eidenmüller, Finanzkrise, Wirtschaftskrise, und das deutsche Insolvenzrecht (Berlin, De Gruyter 2009), p. 23.

${ }^{32}$ P. Jostarndt, Financial Distress, Corporate Restructuring and Firm Survival: An Empirical Analysis of German Panel Data (Berlin, Springer 2007), p. 81. Holdouts can also occur for other reasons, e.g. because the creditor would benefit from the debtor's default: see J.C. Lipson, 'Governance in the Breach: Controlling Creditor Opportunism', 84 S. Cal. L Review (2011), 1035, Part III(B).
} 
restructuring. ${ }^{33}$ If a sufficient number of creditors opt out, the effect may be to scupper negotiations with the remainder. Even where creditors do participate in restructuring negotiations, conflicts between creditors or classes of creditors may prevent final agreement from being reached, as where it is perceived that the effect of the restructuring will be to divert value to one group at the expense of another. ${ }^{34}$ There will also be the additional challenge of dealing with shareholders, given that the terms of any restructuring negotiated with creditors may require the modification or dilution of equity interests. ${ }^{35}$ Again, negotiations may be delayed or scuppered by holdouts or other forms of strategic behaviour on the part of shareholders. The overall result may well be value destructive for the financially distressed debtor. To the extent that this outcome is predictable to investors, this would also be predicted to have an (adverse) impact on the cost and availability of capital ex ante. ${ }^{36}$

Restructuring procedures supplied by law can help to ameliorate the challenges associated with negotiating a restructuring for a financially distressed debtor. Such procedures provide a framework within which debtors can negotiate with their creditors, governed by rules designed to ensure that similarly situated creditors are treated similarly - for example, by the proper constitution of classes, delineated by reference to the similarity of creditors' rights. ${ }^{37} \mathrm{Such}$ procedures will characteristically provide that a restructuring plan approved by a prescribed majority of creditors within each class can, once sanctioned by a court, ${ }^{38}$ bind dissenting creditors to the plan - thus overcoming the holdout problem. ${ }^{39}$ The rules may go further and permit the sanctioning of a plan where a majority of classes agree, binding dissenting classes of creditors to the plan (a "cram down")..$^{40}$ A stay may be imposed to prevent creditors from pursuing debt enforcement action while the plan is being negotiated, or leveraging the possibility of such action to improve their position under the plan. Additionally, some provision may be made for the

${ }^{33}$ M.J. Roe, 'The Voting Prohibition in Bond Workouts', 97 Yale Law Journal (1987), 232, Section I(A) (in the context of US restrictions on the renegotiation of core bond terms) and more generally at 273; H.C. Lee, 'Efficient and Inefficient Debt Restructuring: A Comparative Analysis of Voting Rules in Workouts', 40 Cornell Int'l Law Journal (2007), 661, 668.

${ }^{34}$ Jostarndt, supra n 32, at 82-83; S. Chatterjee, U.S. Dhillon and G.G. Ramirez, 'Resolution of Financial Distress: Debt Restructurings', 25 Financial Management (1996), 5, 13; P. Asquith, R. Gertner and D. Sharfstein, 'Anatomy of Financial Distress: An Examination of Junk-Bond Issuers', 109 Quarterly Journal of Economics (1994), 625, Part IV.

${ }^{35}$ Such a negotiation can be avoided by the transfer of the business to a newly incorporated entity, along with select (restructured) liabilities - see text to $\mathrm{n} 177$ below.

${ }^{36}$ Lee, supra $\mathrm{n} 33$, at 687.

${ }^{37}$ This is the English approach to class constitution in the scheme of arrangement procedure (see J. Payne, Schemes of Arrangement: Theory, Structure and Operation (Cambridge, CUP 2014), pp. 45 et seq.); see also US Bankruptcy Code $\S 1122$ and the German Insolvency Code $\S 222$. On class constitution, see also H. Eidenmüller in H.-P. Kirchhof, R. Stürner and H. Eidenmüller (eds.), Münchener Kommentar zur Insolvenzordnung ( ${ }^{\text {rd }}$ ed., Munich, C. H. Beck 2014), §222, notes 2 et seq.

${ }^{38}$ Judicial scrutiny will typically be necessary to secure compliance with constitutional and/or human rights law, since the effect of the sanctioning of the scheme is to bind dissenting parties to it - resulting in the alteration or extinguishment of rights that they previously enjoyed.

${ }^{39}$ Gilson, supra n 29, at pp. 315-316. It may also be possible for some classes of creditors to commit themselves $e x$ ante to a restructuring procedure set out in a contract, with the result that they can be bound by the agreement of a prescribed majority of the class without recourse to a state-supplied restructuring procedure and a court.

${ }^{40}$ Provision may also be made for binding shareholders to a plan that provides for the elimination or modification of their existing rights. Alternatively, the law may facilitate the transfer of assets along with select (restructured) liabilities to a newly incorporated vehicle, enabling shareholders to be left behind except to the extent they are given an interest in the new entity. See further below, text to $n 177$. 
extension of new finance that under certain conditions can be given priority over existing creditor claims (including secured creditor claims) so as to overcome the "debt overhang" problem that might otherwise deter the extension of working capital to the debtor. ${ }^{41}$

Of course, these features of state-supplied restructuring procedures may also be productive of new challenges. The ability of a majority of classes to bind a minority, for example, could amplify the risk of the procedure being used oppressively by one constituency to obtain a wealth transfer from others. ${ }^{42}$ Difficult questions of valuation will arise when determining who has an economic interest susceptible to expropriation or, in commercial terms, where 'value breaks'. The availability of a stay may incentivise the use of the procedure even where a restructuring would not be value-maximising, as where, for example, the managers of a non-viable business seek to use the procedure for some strategic purpose, or it may incentivise the use of the procedure by a viable debtor that wishes to 'shake off' liabilities it is capable of servicing. ${ }^{43}$ Arrangements for the provision of new finance on terms that the financier will enjoy "super priority" will raise complex questions about whether existing creditors are adequately protected, particularly where the offer of new finance comes from an existing creditor who hopes to improve the priority position of his or her pre-existing claim as part of the arrangement. ${ }^{44}$ Judicially administered safeguards to guard against oppression and abuse will be required ${ }^{45}$ and there will of course be direct costs associated with their administration - along with the costs of an application to court for sanction of the plan. Despite all this, there will be some circumstances in which recourse to a state-supplied restructuring procedure represents the most attractive route to value preservation for a financially distressed debtor. ${ }^{46}$ The Restructuring Recommendation is concerned with the availability and design of such procedures in the Member States of the European Union.

\section{The Background to the Release of the Recommendation}

The initial impetus for the Recommendation came from the publication of qualitative evidence of variation in the availability and efficiency of debt restructuring procedures across Member States. The most detailed evidence of this kind appeared in a 2010 report produced by INSOL Europe on the desirability and practicability of harmonising national insolvency laws in the EU. ${ }^{47}$ Drawing on the results of a questionnaire circulated to INSOL Europe members in seven Member States

\footnotetext{
${ }^{41}$ K. Ayotte and D.A. Skeel, 'Bankruptcy Law as Liquidity Provider', 80 University of Chicago Law Review (2013), 1557, Part II.

${ }^{42}$ Lee, supra $\mathrm{n} 33$, at 685-686. Of course, to the extent that investors anticipate and price in the risk of this, the outcome is not properly characterised as a transfer vis-à-vis those investors: M.C. Jenson and W.H. Meckling, 'Theory of the Firm: Managerial Behaviour, Agency Costs and Ownership Structure', 3 Journal of Financial Economics (1976), 305, 336.

${ }^{43}$ S. Paterson, 'Rethinking the Role of the Law of Corporate Distress in the Twenty-First Century' (LSE Law, Society and Economy Working Papers 27/2014), p. 18.

44 The control enjoyed by the new financier during the restructuring process may also lead to value-diminishing outcomes: D.A. Skeel, 'The Past, Present and Future of Debtor-in-Possession Financing', 25 Cardozo Law Review (2004), 1905.

${ }^{45}$ Lee, supra $\mathrm{n} 33$, at 687-688.

${ }^{46}$ For example, because the debtor is facing a liquidity crisis that renders prolonged informal negotiations impractical (for empirical evidence consistent with this, see Chatterjee, Dhillon and Ramirez, supra $\mathrm{n}$ 34), or because the heterogeneity of creditor claims makes it difficult to reach private agreement ex post or to design a contractual restructuring procedure to facilitate this ex ante.

47 INSOL Europe, Harmonisation of insolvency law at EU level, supra $\mathrm{n} 17$.
} 
(France, Germany, Italy, Poland, Spain, Sweden and the UK) and the experiences of the reporters in other jurisdictions, the report identified a number of differences in restructuring laws across the EU - including as to when formal reorganisation procedures could be initiated, ${ }^{48}$ and as to how reorganisation / restructuring plans were to be proposed ${ }^{49}$ voted on $^{50}$ and sanctioned. ${ }^{51}$ These differences were reported to have produced an uneven playing field, in which some debtors had better prospects of restructuring than others. They were also said to have incentivised forum shopping, and to have acted as a barrier to the adoption of restructuring plans in cross-border cases. ${ }^{52}$ The report recommended harmonisation of a range of rules, including those governing the proposal of a restructuring plan and its permissible contents, the extent to which creditors and shareholders could be bound by it, the composition of creditors and shareholders in classes, voting rules, the judicial sanction of plans and appeals from such decisions, and the amendment or "rescission" of plans. ${ }^{53}$ The report also identified other areas of national insolvency law in which swift harmonisation was desirable, including aspects of transaction avoidance law, the treatment of executory contracts on the commencement of proceedings, and the coordination of proceedings relating to members of a corporate group..$^{54}$

The INSOL Europe report was prepared at the request of the European Parliament's Committee on Legal Affairs, and the Committee was quick to embrace its conclusions. A parliamentary resolution was passed on 15 November 2011, recommending harmonisation of aspects of the rules governing the opening of insolvency proceedings, the filing of creditor claims, transaction avoidance laws, the work and qualifications of insolvency practitioners, and "aspects of the establishment, effects and content" of court-approved restructuring plans, inter alia. ${ }^{55}$ The resolution's recitals emphasised the importance of rescuing distressed debtors ${ }^{56}$ and the role of the formal law in facilitating this. ${ }^{57}$ Disparities between the laws of Member States were identified as an obstacle to the restructuring of distressed debtors, and relatedly as a source of competitive disadvantage (for those less well positioned to achieve a restructuring), and of forum shopping (for those able to engage in forum shifts to overcome this disadvantage) ${ }^{58}-$ a practice that the Parliament aimed to limit. ${ }^{59}$ The Resolution tasked the European Commission with preparing a

\footnotetext{
48 ibid 1(I)(i).

49 Particularly by whom they could be proposed: ibid 1(VI)(i).

50 "In some jurisdictions the creditors are divided up into different classes, in others they are not": ibid 1(VI)(ii).

51 "The laws of the Member States also contain different rules on the standards applied by the courts when reviewing the plan and appeal possibilities": ibid.

52 ibid p. 17.

53 ibid.

${ }^{54}$ ibid 2.1, and 1(VIII), (IX). Part 1 also identified some other areas in which harmonisation was desirable in the longer term, including the rules governing the liability of directors of distressed companies ( $\mathrm{Pt} 1(\mathrm{X})$, and see also $\mathrm{Pt}$ 3(iii)), the criteria for the opening of insolvency or reorganisation proceedings (Pt 1(I)), and the rules governing the filing and verification of claims for the purpose of facilitating a distribution in insolvency proceedings (Part 1(V)).

55 European Parliament Committee on Legal Affairs, Report with recommendations to the Commission on insolvency proceedings in the context of EU company law (A7-0355/2011, 17 October 2011), Annex Part 1.

${ }^{56}$ Resolution, supra n 20, Recital I: "whereas the approach in relation to insolvency proceedings is now centred more on corporate rescue as an alternative to liquidation".

57 ibid Recital J: "whereas insolvency law should be a tool for the rescue of companies at Union level”.

58 ibid Recital A.

59 ibid Recital B: "whereas steps must be taken to prevent abuse, and any spread, of the phenomenon of forum shopping".
} 
legislative proposal. ${ }^{60}$ The following year, the Commission's second Communication on the Single Market Act identified insolvency law reform (specifically the introduction of "modern insolvency laws that help basically sound companies to survive") as a "priority action" for the strengthening of the internal market, and promised investigation into how the efficiency of Member State laws could be improved "with a view to creating a level playing field". ${ }_{1}$

The Commission's first substantive response appeared later in 2012 with the release of its Communication "A new European approach to business failure and insolvency". ${ }^{22}$ The Commission identified six areas of divergence between the insolvency laws of Member States that in its view produced competitive disadvantages for some debtors and/or their creditors and had "the greatest potential to hamper the establishment of an efficient insolvency legal framework in the internal market" ${ }^{63}$ One of these was in the rules governing the opening of insolvency procedures, although - unlike Parliament - the Commission focused rather more on the impact of such rules on the ability of financially distressed debtors to restructure. In the Commission's view, variation in the rules on the opening of insolvency proceedings had resulted in "varying chances for restructuring", with some debtors more likely than others to be inhibited by such rules from negotiating a workout with creditors - perhaps because (although the Communication is not entirely clear on this point) under the applicable national law they would be likely to be propelled into an insolvency procedure at an earlier point in time. ${ }^{64}$

Consistent with the Resolution, a second area of divergence highlighted in the 2012 Communication was in the design of Member States' formal restructuring procedures. Of particular concern to the Commission were differences in Member State rules on the proposal of restructuring plans, the adoption of plans by creditors (including the rules on creditor class constitution, and the majority required to accept the plan before it could be made binding on others), and the sanctioning of plans by courts (including the standard by which judges were required to evaluate a plan approved by the requisite majority, and the extent of their discretionary powers) ${ }^{65}$ More generally, the Commission warned against "rigid and impracticable rules" that could "hinder the chance of adopting a restructuring plan, leaving no alternative but to wind up a company" ${ }^{66}$ Respondents to a public consultation, in which participants were asked about the utility of harmonisation in this and other areas, broadly affirmed the claim of problematic divergence in national laws: approximately two thirds answered "yes" to the question "is there a need to eliminate all or some of the divergences of national rules regulating restructuring plans?" ${ }^{67}$ The Recommendation followed.

\footnotetext{
60 ibid 1.

${ }^{61}$ European Commission, Communication from the Commission to the European Parliament, The Council, The European Economic and Social Committee and the Committee of the Regions - Single Market Act II: Together for new growth, $\operatorname{COM(2012)~573,~} 3$ October 2012, Key Action 7 (p. 11).

${ }^{62}$ European Commission, Communication from the Commission to the European Parliament, the Council and the European Economic and Social Committee: A new European approach to business failure and insolvency, $\operatorname{COM}(2012)$ 724, 12 December 2012.

${ }^{63}$ ibid pp. 2-3.

${ }^{64}$ ibid Section 3.3.

65 ibid Section 3.6.

66 ibid.

${ }^{67} 126$ respondents answered "yes", 39 answered "no": European Commission, Consultation on a new European approach to business failure and insolvency [online]. Available at http://ec.europa.eu/yourvoice/ipm/forms/dispatch?userstate=DisplayPublishedResults\&form=InsolvencyTwo (accessed 21 August 2015), Q5. When asked which area of divergence was most problematic, the two most common
} 
The Commission's work in restructuring law has been conducted against the backdrop of the crisis and is at least in part a response to it. This is perhaps most evident from the Commission's 2012 Communication, the introduction to which describes the crisis and calls for a "European response" to "create an efficient system to restore and reorganise business so that they can survive the financial crisis..." ${ }^{68}$ This may explain why proposals for harmonisation in restructuring have been pursued with speed relative to other proposals made by the Parliament for harmonisation in insolvency law - proposals that appear less obviously connected with the Commission's 'restoration and reorganisation' goal. The crisis context may also help to explain the Commission's apparently exclusive focus on restructuring as the route to maximising the value of the business of a financially distressed debtor. One obvious alternative to reorganising such a debtor - that is, restructuring liabilities (and perhaps assets) so as to enable the debtor to itself continue to carry on the whole or some part of its business - is to sell the business (on a going concern basis) to a new (third party) owner, in an auction. In general, such an auction might be regarded as the more attractive route to value preservation, since it dispenses with the need for (costly) bargaining with stakeholders to secure a restructuring of liabilities. ${ }^{69}$ In times of crisis, however, illiquid markets may create the risk of auctions at "fire sale" prices $^{70}$ - and indeed the risk of sales on a break-up basis, producing a result equivalent to liquidation (i.e. the loss of going concern value). In other words, in times of crisis the Commission's dichotomy restructure or liquidate $^{71}$ - may more accurately represent the options available to debtors. ${ }^{72}$ As a consequence, lawmakers may be (quite apart from any political economy considerations associated with the unemployment consequences of business failure) particularly interested in reform of restructuring law in times of crisis. More specifically, they are likely to be drawn to procedures that facilitate the negotiation of a restructuring plan by the debtor's existing managers under the protection of a stay that offers (temporary) relief against the risk of value-destructive liquidation. ${ }^{73}$ As it turns out, this is precisely the kind of procedure contemplated by the Recommendation.

answers were (a) "the required majorities for approving the plan / voting rules" (24 of the 126 affirmative responses) and (b) "the criteria for approving the plan by the supervising court" (19 of 126 affirmative responses).

${ }^{68}$ Communication, supra $\mathrm{n} 62$, at p. 2.

${ }^{69}$ D. Baird, 'The Uneasy Case for Corporate Reorganizations', 15 Journal of Legal Studies (1986), 127, acknowledging however that there are cases where a transfer of crucial assets to a new entity is not feasible (see Section IV 3(a)).

${ }^{70}$ As modelled by A. Shleifer and R. Vishny, 'Liquidation Values and Debt Capacity: A Market Equilibrium Approach', 47 The Journal of Finance (1992), 1343 (focusing on industry distress); see also Gertner and Scharfstein, supra $\mathrm{n} 28$, at 1216 ("if the market for the sale of distressed firms is thin and inefficient, the buyer will get some rents. This will inefficiently increase the firm's ex ante cost of capital since neither original shareholders nor creditors receive these rents"). Some empirical evidence runs counter to this prediction: see B.E. Eckbo and K.S. Thorburn, 'Economic Effects of Auction Bankruptcy' (Tuck School of Business Working Paper No 2009-63, 2009).

${ }^{71}$ Text to $\mathrm{n} 66$ above, and see also the European Commission, Impact Assessment accompanying the document Commission Recommendation on a New Approach to Business Failure and Insolvency (Commission Staff Working Document), SWD(2014) 61 final, p. 2: "An effective insolvency law should be able to liquidate speedily and efficiently unviable firms and restructure viable ones...". A recent Commission discussion paper (n 17) indicates continuing use of this dichotomy.

${ }^{72}$ Consistent with this analysis, see Impact Assessment, ibid p. 24.

73 J. Suarez and O. Sussman, 'Financial distress, bankruptcy law and the business cycle', 3 Annals of Finance (2007), 5, 7 and Part 6 (modelling the weaknesses of this reform strategy in the long run). As Suarez and Sussman allude to, restructuring law reforms were made in a number of jurisdictions following the East Asian Financial Crisis (as to which, see also S. Claessens, S. Djankov and A. Mody, Resolution of Financial Distress: An International Perspective on the Design of Bankruptcy Laws (Washington, IDRD 2001)). For earlier examples of restructuring reforms in times of crises, see J. Percerou and K.H. Nadelmann, 'Changes in Bankruptcy Procedure and Schemes of Arrangement with Creditors Caused by the Economic Crisis', 12 Nat'l Ass'n Ref. Bankr. (1938), 68, Part II. 


\section{The Regulatory Strategy: Non-binding "Minimum Standards"}

The principal objective of the Recommendation is to "encourage Member States to put in place a framework that enables the efficient restructuring of viable enterprises in financial difficulty... thereby promoting entrepreneurship, investment and employment and contributing to reducing the obstacles to the smooth functioning of the internal market" (RR No. 1). In pursuit of this objective, the Recommendation encourages each Member State to ensure that its national law offers debtors a "preventative restructuring framework" that complies with certain prescribed "minimum standards" (RR No. 3). By "preventative restructuring framework" the Commission means a procedure provided by law that enables a debtor to achieve a restructuring "with the objective of preventing insolvency" (RR No. 6). ${ }^{74}$

The Commission's "minimum standards" are essentially a set of core prescriptions or principles for the design and implementation of such restructuring procedures: in other words, the Commission recommends that Member States ensure that they offer a procedure that, at a minimum, complies with these principles. The regulatory strategy, then, is to encourage convergence in those areas that the Commission regards as core to the functionality of debt restructuring procedures, whilst leaving other aspects of the design and implementation of such procedures to Member States. ${ }^{75}$ The assumption appears to be that the Commission's core principles are so fundamental that encouraging Member State compliance with them could be expected to improve the prospects of distressed debtors achieving a value-maximising restructuring (and in this way improve investment incentives ex ante), notwithstanding the persistence of other differences in Member State laws and legal institutions (e.g. courts).

The Recommendation sets out six core principles that Member States are urged to adhere to in designing their restructuring "framework" or procedure for business debtors. These principles are:

(1) Pre-insolvency recourse: the Commission recommends that a debtor be able to have recourse to a restructuring procedure "at an early stage, as soon as it is apparent that there is a likelihood of insolvency" (RR No. 6(a)). This principle appears to have been designed in recognition of costs of financial distress - an earlier restructuring representing an opportunity to reduce such costs. ${ }^{76}$ In Member States where formal restructuring tools are presently contained within insolvency procedures that can only be initiated on the debtor's insolvency, adherence to this principle would require a change in the law to make such tools available earlier - without recourse to the insolvency procedure. ${ }^{77}$ The Recommendation does not, however, express unqualified commitment to a principle of early recourse. Instead, the Commission recommends confining

\footnotetext{
${ }^{74}$ See also Impact Assessment accompanying the Recommendation, supra $\mathrm{n}$ 71, at p. 2.

${ }^{75}$ This is consistent with Weatherill's observations on trends in EU harmonisation more generally: "It is plain that harmonisation, conventionally understood as a process of generating common rules for a common market, increasingly exists with other 'softer' forms of governance and a general willingness to tolerate, even extol, a higher degree of flexibility and diversity in coverage under the EU umbrella than would previously have been imagined to be feasible... This raises the possibility of an EC contribution to the regulation of a particular area that is pitched at a less dogmatic level than would be expected of traditional harmonisation": S. Weatherill, 'Why harmonise?' in Tridimas, T. and Nebbia, P. (eds.), European Law for the Twenty-First Century: Volume 2 (Oregon, Hart 2004), p. 16.

${ }^{76}$ See Impact Assessment accompanying the Recommendation, supra n 71, at p. 7: "As a general observation, the later a business initiates restructuring proceedings, the higher the costs of restructuring and the lower the management powers and the success rate"; see also Recital 16 of the Recommendation. As to the costs of financial distress, see $\mathrm{n} 28$ above.

${ }^{77}$ RR Recital 2. For jurisdictional examples, see Impact Assessment, supra n 71, at pp. 11-12.
} 
access to the procedure to debtors already "in financial difficulties when there is a likelihood of insolvency" ${ }^{78}$ This qualification appears to be designed to ameliorate the risk (referred to above $)^{79}$ of misuse of the procedure by solvent debtors - for example, to coerce compromise where the debtor is capable of fulfilling its existing obligations. ${ }^{80}$

(2) Minimised court involvement: the Commission recommends that a debtor be able to have recourse to its pre-insolvency restructuring procedure without the need to obtain any formal court order (RR No. 8). This recommendation appears designed to reduce both the direct costs associated with use of the procedure (since every application and appearance is costly), but also some of the indirect costs associated with its use. The Impact Assessment accompanying the Recommendation suggests that the ability to initiate the procedure without a court order may permit a debtor to commence restructuring negotiations without publicising to all creditors and counterparties that it has done so - thereby avoiding, for example, the need to give early notice to creditors from whom the debtor will not in fact be seeking a compromise (e.g. those whose continuing relationship with the debtor is considered essential to the preservation of its going concern value, such that their claims will be met in full during the restructuring process) ${ }^{81}$ At the same time, the Commission recognises that these negotiations are commenced with a view to achieving a plan that, where approved by the requisite majority of affected creditors and sanctioned by the court (principle (5) below), will bind dissenting creditors. Since this raises the prospect (as discussed in Section II (1) above) of the procedure being used oppressively - that is, being used by one constituency to extract wealth from others - the Commission accepts that the court has a central role in guarding against this. ${ }^{82}$ The court's involvement in the restructuring process should, however, be limited to that "necessary and proportionate with a view to safeguarding the rights of creditors and other interested parties affected by the restructuring plan" (RR No. 7) ${ }^{83}$ The overarching goal is to encourage the availability of restructuring procedures that are quick to conclude (given the need to continue operations to preserve value, the challenges of ensuring sufficient cash flow to enable this, and the rising costs of financial distress) and inexpensive to have recourse to. ${ }^{84}$

(3) Debtor-in-possession: consistent with its goal of ensuring business continuity while the restructuring is negotiated, the Commission recommends that the debtor "keep control over the day-to-day operation of its business" while the restructuring framework is used (RR No. 6(b)) ${ }^{85}$ As the Impact Assessment explains, this may also help to incentivise early initiation of the restructuring procedure (given managers need not fear automatic displacement on doing so), ${ }^{86}$ consistent with principle (1). The Commission contemplates national law making provision for a

\footnotetext{
${ }^{78}$ The definition of “debtor" in RR No. 5(a); see also RR No. 6(a) and Recital 16.

79 Text to $\mathrm{n} 43$.

${ }^{80}$ RR Recital 16: "in order to avoid any potential risks of the procedure being misused, the financial difficulties of the debtor must be likely to lead to insolvency". The Impact Assessment accompanying the Recommendation, supra $\mathrm{n} 71$, at Section 7.2.1, suggests that the Commission feared that relaxing this financial qualification would require increased judicial scrutiny to control abuse of the procedure, which would increase the direct costs of its use.

${ }^{81}$ Impact Assessment accompanying the Recommendation, supra n 71, at p. 10 fn. 26 and p. 11.

${ }^{82}$ RR Recital 19.

${ }^{83}$ See also Recital 17, and Impact Assessment accompanying the Recommendation, supra $\mathrm{n}$ 71, at Section 7.2.6, contemplating a preventative procedure in which the court 'needs only to be involved at 2 moments': the imposition of a moratorium on enforcement action (principle (4)), and the sanctioning of a plan.

${ }^{84}$ Impact Assessment accompanying the Recommendation, supra n 71, at pp. 14-15.

${ }^{85}$ ibid Section 7.2.3.

86 ibid p. 10.
} 
court-appointed mediator (to facilitate negotiations with creditors) or court-appointed supervisor (to "oversee the activity of the debtor and creditors" and safeguard the "legitimate interests" of creditors and other stakeholders), but recommends against the automatic appointment of either (RR No. 9). The Impact Assessment acknowledges that there are some jurisdictions in which formal restructuring tools are provided only within the context of a manager displacing insolvency procedure. ${ }^{87}$ For such jurisdictions, the Commission does not appear to be recommending amendments to these insolvency procedures - rather, it appears to be contemplating the introduction, alongside any such insolvency procedure, of an additional debtor-in-possession restructuring procedure accessible before factual insolvency arises (provided its "financial difficulties" test is satisfied: principle (1)).

(4) Court-ordered stay of enforcement action: the Commission recommends that the debtor be empowered to apply to court for the imposition of a stay of individual creditor enforcement action (including by secured creditors, RR Nos. 5(c), 6(c) and 10), thus enabling it to resist the piecemeal dismemberment of the business (or strategic threats to do so) during the pendency of restructuring negotiations. It is primarily for Member States to determine the conditions under which such a stay would be granted, but the Commission does recommend that a stay be available where creditors with a "significant" amount of claims likely to be affected by the plan support the negotiations, and the plan has a "reasonable prospect of being implemented and preventing insolvency of the debtor" (RR No. 11). The Recommendation is more prescriptive about the length of any such stay, the Commission clearly anxious about the likely impact that a stay of indeterminate duration (in effect, a mandatory maturity extension of indeterminate length ${ }^{88}$ would have on the cost and availability of credit ex ante.$^{89}$ It recommends that the stay be set by reference to the complexity of the restructuring and the need to strike a "fair balance" between the interests of the debtor and of its creditors, but that the stay be initially limited to a period not exceeding four months. Member States could provide for renewal, but only on the debtor providing evidence of progress in the negotiations, and subject to a maximum total duration of 12 months (RR No. 13). The Commission further recommends that Member States oblige the court to lift the stay wherever it is no longer necessary to facilitate the plan's adoption (RR No. 14).

The stay contemplated by the Recommendation is a stay of "enforcement action" by creditors (a "suspension of the right to enforce a claim by a creditor against a debtor": RR No. 5(c)), but the Commission does recommend that when such a stay is ordered it should also have the effect (for the duration of the stay) of "suspending" an obligation a debtor might otherwise have to file for insolvency proceedings (i.e. a mandatory filing rule), and of suspending applications by creditors for the commencement of such proceedings (RR No. 12). Apart from this specific recommendation, the Commission leaves much to Member States to determine about the design of the stay. The Recommendation is silent, for example, on the question of whether and under what conditions litigation against the debtor (readily distinguishable from "enforcement") should be stayed. There is little discussion of the treatment of executory contracts: the Commission indicates that its stay on enforcement action should "not interfere with the performance of ongoing contracts" (RR No. 10), but does not explain what this means for the treatment of liabilities arising after the commencement of restructuring negotiations under executory contracts (should these and other post-commencement liabilities be paid, and - if they are not - are such creditors also to be restrained from enforcing?), nor does the Commission make any specific

\footnotetext{
87 ibid p. 33.

${ }^{88}$ Gertner and Scharfstein, supra n 28, at 1210.

${ }^{89}$ Impact Assessment accompanying the Recommendation, supra n 71, at p. 31.
} 
recommendation as to the treatment of provisions in executory contracts that permit the termination or modification of the debtor's rights on recourse to a restructuring procedure.

(5) Ability to bind dissenting creditors to plan through expedient court confirmation: the Commission recommends that "a restructuring plan adopted by the majority prescribed by national law should be binding on all creditors provided that the plan is confirmed by a court" (RR No. 6(d)). Despite the reference to "all creditors", the Commission elsewhere makes clear that Member States should permit the use of their restructuring procedure by debtors seeking to restructure only select liabilities or classes of liability (secured or unsecured) ${ }^{90}$, with other creditors excluded from the plan - "provided that [these] other creditors are not affected" (RR No. 20).$^{91}$ Where those creditors included in the plan have "different interests", the Commission recommends they be grouped into separate classes for the purpose of eliciting their approval to the plan; at a minimum, it recommends that secured and unsecured creditors be treated as distinct classes (RR No. 17). The Recommendation does not prescribe how such creditor approval is to be elicited, leaving it to Member States to decide on the procedure. ${ }^{92}$ Nor does it prescribe what majority of creditors in each class must offer approval before the plan is eligible for court confirmation. This is left to national law, along with the important question of whether a plan that is approved by (the requisite majority in) some classes but not others can be confirmed by the court, and if so whether the effect of this confirmation would be to bind dissenting classes to the scheme. On the latter question of the availability of a cram-down power, the Commission appears to adopt a neutral approach, suggesting that Member States "should be able to maintain or introduce" such a power, but without saying whether it recommends they do so (RR No. 18). ${ }^{93}$

The Commission does, however, ask Member States to issue "clear and specific" rules on the content of restructuring plans, and it recommends that these include a requirement that the plan explain its potential "to prevent the insolvency of the debtor and ensure the viability of the business" (RR No. 15(e)). Courts should be expressly empowered to reject plans that "clearly do not have any prospect of preventing the insolvency of the debtor and ensuring the viability of the business" (RR No. 23). The Commission also recommends that Member States issue clear rules setting out the conditions under which a plan can be confirmed by a court, so as to render it binding on dissenting creditors or (where national law so provides) classes of creditor (RR No. 22).$^{94}$ It recommends a series of conditions, both procedural (including that the plan has been notified to all creditors "likely to be affected by it", that they have been given the opportunity to object, and that they will be able to appeal against it ${ }^{95}$ and substantive - including that the plan does not reduce the rights of dissenting creditors beyond what they could be expected to receive without the restructuring, "if the debtor's business was liquidated or sold as a going concern, as the case may be" (RR No. 22(c)), and that any new finance foreseen in the plan is necessary for

\footnotetext{
${ }^{90}$ RR No. 16.

${ }^{91}$ As to the ambiguity in the word "affected", see Section IV 3(c) below.

${ }^{92}$ Except for a recommendation that distance communication should be permissible wherever the "the laws of the Member State require a formal voting process": RR No. 19. The silence of the Recommendation on other aspects of voting procedure appears to be a deliberate attempt to permit Member States to remove the need for formal meetings and otherwise reduce voting formalities: see Impact Assessment accompanying the Recommendation, supra $\mathrm{n}$ 71, Section 7.2.4.

${ }^{93}$ See also Impact Assessment accompanying the Recommendation, supra n 71, Section 7.2.4.

${ }^{94}$ RR No. 21 makes clear that a plan that will "affect the interests of dissenting creditors" (i.e. one for which unanimous consent has not been given by affected creditors) must be court sanctioned to become binding.

${ }^{95}$ RR No. 22(b) and RR No. 24, noting that an appeal should "not in principle suspend the implementation of the restructuring plan". More generally, RR No. 22(a) recommends that courts be required to confirm that the plan has been "adopted in conditions which ensure the protection of the legitimate interests of creditors".
} 
its implementation and does not "unfairly prejudice the interests of dissenting creditors" (RR No. 22(d)). Finally, assuming these conditions are satisfied, the Recommendation tasks Member States with ensuring that courts are equipped to confirm plans "with expediency and in principle in written procedure", i.e. without an oral hearing (RR No. 15).

(6) Protection for new finance: in an effort to encourage the extension of new finance to debtors negotiating a restructuring, the Commission recommends that those who provide new finance under a court-sanctioned restructuring plan be shielded from the operation of transaction avoidance rules that could otherwise render the transaction "void, voidable or unenforceable as an act detrimental to the general body of creditors" (RR No. 27; see also RR No. 6(e)), and from "civil and criminal liability relating to the restructuring process" (RR No. 28), except in the case of fraud (RR No. 29). The Recommendation is silent on the treatment of new finance extended between the commencement of the procedure and plan confirmation, leaving it to national law to determine the priority to be afforded to such finance, ${ }^{96}$ and the impact of transaction avoidance rules on its validity.

\section{The Restructuring Recommendation and the Reform of the EIR}

The European Commission's "preventative restructuring framework" for Member States is intended to operate in tandem with, and be complemented by, the jurisdictional and private international law framework set up by the EIR. The EIR was born out of an acknowledgement that the establishment and promotion of the internal market would be associated with an increase in the number of insolvencies with one or more cross-border elements. ${ }^{97}$ Such cross-border cases would raise a series of coordination problems. The familiar challenge of coordinating creditors so as to resist the piecemeal dismemberment of assets worth more kept together would become more complex and more costly, given the prospect of creditor asset 'grabs' occurring in multiple Member States simultaneously. ${ }^{98}$ Insolvency proceedings could be opened in every Member State in which the debtor had assets (so as to invoke the application of local moratoria), but multiple insolvency proceedings would also be a threat to the preservation of going concern value unless such proceedings could be effectively coordinated. The treatment of the debtor's liabilities would also become more complex, particularly in those cases in which the value maximising outcome would be a reorganisation - i.e. the survival of the debtor with its business, its liabilities having been restructured. The presence of creditors abroad could make it more difficult to negotiate a restructuring, for there might be uncertainty as to whether a restructuring plan agreed in one jurisdiction would be recognised as binding in others. Local creditors may be unwilling to

\footnotetext{
96 The Impact Assessment indicates that the Commission was anxious about the impact of recommending a super priority rule on secured creditor rights: supra $\mathrm{n} 71$, Section 7.2.5.

${ }^{97}$ J. Noel and J. Lemontey, Report on the Convention Relating to Bankruptcies, Compositions and Analogous Procedures (Commission of the European Communities Working Document 16.775/XIV/70, 1970), p. 8: "[In a "genuine and vast" internal market] the various components of assets and creditors of many enterprises will be more and more spread over different States... If some of them are not in a position to face up to their obligations, the effects of bankruptcy or similar measures pronounced against them will extend beyond the frontiers of a single State". The Noel and Lemontey report accompanied the first in a series of draft bankruptcy conventions for the E.E.C., which eventually culminated in the negotiation of a 1995 convention that was subsequently enacted as the European Insolvency Regulation 1346/2000: see the historical review in K. van Zwieten, 'An introduction to the European Insolvency Regulation' in R. Bork and K. van Zwieten (eds.), Commentary on the European Insolvency Regulation (forthcoming, OUP 2016).

98 J.L. Westbrook, 'Theory and Pragmatism in Global Insolvencies: Choice of Law and Choice of Forum', 65 American Bankruptcy Law Journal (1991), 457, 460.
} 
participate in restructuring negotiations if they cannot be confident that foreign creditors ${ }^{99}$ will be restrained from attempting to enforce pre-plan claims against the debtor as if those claims had not been validly restructured. ${ }^{100}$ Again, the commencement of parallel (reorganisation) proceedings abroad might assist, but only if they could be coordinated so as to produce equivalent and binding plans at reasonable cost. Such coordination might however be difficult to achieve, given differences in national substantive and procedural insolvency law rules.

The EIR, both as originally enacted and as recast, responds to these coordination challenges by restricting when insolvency proceedings (as defined in the Regulation) can be opened in Member States, and by regulating the scope and effects (including extraterritorial effects) of those proceedings validly opened under it. The basic strategy is one of modified universalism. The EIR provides for the opening of "main" insolvency proceedings in one Member State (the place of the debtor's COMI) governed primarily by the law of that State, ${ }^{101}$ which are afforded automatic recognition in other Member States ${ }^{102}$ and produce "the same effects" in them as under the law of the state in which the main proceedings were opened, ${ }^{103}$ except to the extent the Regulation otherwise provides (such exceptions including, perhaps most notably, the insulation of rights in rem over assets situated in other Member States from the effects of the opening of proceedings). ${ }^{104}$ These extraterritorial privileges are designed to ensure that main proceedings enjoy "universal" - or, more precisely, EU-wide - scope, encompassing assets and (unsecured) creditors throughout the EU ${ }^{105}$ The universalism is a "modified" one because the EIR also permits the parallel opening of rival proceedings ${ }^{106}$ in Member States where the debtor has an "establishment", ${ }^{107}$ although these are restricted in scope to local assets. ${ }^{108}$ With the exception of these, however, the opening of other insolvency proceedings (again, as defined) is prohibited - so as to facilitate the resolution of distress in a single forum, the place of the "main" proceedings.

Under Article 46 of the original EIR, the Commission was obliged to carry out a review of the operation of the Regulation, and to report on this in 2012 (ten years after it entered into force). As part of this review, several external studies were commissioned, including an extensive evaluation of the operation of the EIR in 26 Member States. This study (the "Heidelberg

\footnotetext{
${ }^{99}$ Particularly foreign creditors whose claim is governed by a law other than the law of the forum, for the conflict of laws rules of many jurisdictions would recognise a compromise validly effected under the law of the liability: see, e.g., I. Fletcher, Insolvency in Private International Law (2 ${ }^{\text {nd }}$ ed., Oxford, OUP 2005), Section 2.7.

${ }^{100}$ This may also reduce the prospects of attracting new finance during restructuring negotiations: J.L. Westbrook, 'Chapter 15 and Discharge', 13 ABI Law Review (2005), 503, 505.

${ }^{101}$ Article 4, subject to the exceptions and qualifications in Articles 5-15 of the EIR 1346/2000; Articles 7-18 of the recast EIR 2015/848. Note that these provisions are designed to regulate only the intra-EU effects of the Regulation: M. Virgos and F. Garcimartin, The European Insolvency Regulation: Law and Practice (Dordrecht, Kluwer Law International 2004), p. 91.

${ }^{102}$ Article 16 of EIR 1346/2000, subject to the public policy exception in Article 26; Articles 19 and 33 of recast EIR $2015 / 848$.

${ }^{103}$ Article 17(1) of EIR 1346/2000; Article 20(1) of recast EIR 2015/848.

${ }^{104}$ Article 5 EIR 1346/2000; Article 8 recast EIR 2015/848. See further below, text to nn 136 et seq.

${ }^{105}$ Except to the extent that rival (secondary) proceedings are opened.

${ }^{106}$ Under the EIR 1346/2000 these proceedings were limited to winding-up proceedings (Art. 3(3)), but this restriction has been relaxed in the recast EIR.

${ }^{107}$ Defined to require more than the presence of assets: EIR 1346/2000 Art. 2(h); recast EIR 2015/848 Art. 2(10).

${ }^{108}$ Art. 3(2) of EIR 1346/2000 and recast EIR 2015/848.
} 
Report") ${ }^{109}$ concluded that the EIR was "generally regarded as a successful instrument for the coordination of the insolvency proceedings of the EU Member States" ${ }^{110}$ and recommended that its basic structure be preserved. The report did, however, identify a number of areas in which the functionality of the EIR could be improved. One of these was the scope of the EIR, and specifically the kind of insolvency procedures to which it applied. The question of scope is of course central to the operation of the EIR, for it is only proceedings falling within its scope that can become "main" proceedings under it with consequential extraterritorial privileges throughout the EU. Similarly, the jurisdictional bar imposed by the EIR on the opening of insolvency proceedings that are neither main nor permitted local proceedings only applies to those insolvency proceedings falling within its scope.

Article 1(1) of the original EIR provides that the Regulation applies to proceedings that are "collective insolvency proceedings which entail the partial or total divestment of the debtor and the appointment of a liquidator". ${ }^{111}$ Article 2 provides:

'Insolvency proceedings' shall mean the collective proceedings referred to in Article 1(1). These proceedings are listed in Annex A ...

'Liquidator' shall mean any person or body whose function is to administer or liquidate assets of which the debtor has been divested or to supervise the administration of his affairs. Those persons and bodies are listed in Annex C.

The Heidelberg Report concluded that the relationship between the substantive definitions in Article 1 and 2 and the Annexes was unhelpfully and unnecessarily ambiguous. ${ }^{112}$ More fundamentally, it found the substantive definitions in Articles 1 and 2 to be too narrow. It reported that many Member States had introduced one or more "quasi-collective procedures"113 designed to enable a debtor to avoid insolvency by achieving a corporate restructuring "under the supervision of a court or an administrative authority". ${ }^{114}$ Such procedures, which left debtors in possession during the pendency of restructuring negotiations, appeared to fall entirely outside the EIR $^{115}$ - given they were not proceedings entailing the "partial or total divestment of the debtor and the appointment of a liquidator". Wherever such proceedings fell outside the scope of the EIR, the Regulation's provisions on jurisdiction, applicable law, recognition, and extraterritorial effects could not be invoked - reportedly leading to considerable complexity and uncertainty in practice. ${ }^{116}$ The Report recommended widening the scope of the EIR to extend to "pre-insolvency proceedings aimed at rescuing or reorganising the debtor's estate", subject to certain conditions. ${ }^{117}$

\footnotetext{
${ }^{109}$ External Evaluation of Regulation No. 1346/2000 on Insolvency Proceedings (JUST/2011/JCIV/PR/0049/A4), presented by B. Hess, P. Oberhammer and T. Pfeiffer.

${ }^{110}$ ibid p. 10.

${ }^{111}$ Apart from those proceedings listed in Art. 1(2).

112 viz. "Does the Regulation apply to a national insolvency procedure which is not listed in the Annexes, but which corresponds to the definition of Article 1(1) EIR? Does the Regulation apply to national procedures which are listed in the Annex, but do not correspond to the definition of Article 1(1) EIR?": supra n 109, at p. 11; see also p. 36. The same ambiguity afflicts the definition of "liquidator" in Article 2.

${ }^{113}$ That is, proceedings that do not necessarily encompass or affect the entire body of creditors: supra n 109 p. 38.

${ }^{114}$ Heidelberg Report, supra n 109, at pp. 11, 38.

${ }^{115}$ Although the Heidelberg Report also found that some Member States had succeeded in having procedures added to Annex A that did not comply with the substantive definitions in Arts. 1-2: supra n 109, at p. 40.

${ }^{116}$ ibid pp. 38-40.

${ }^{117}$ ibid Section 2.2.2.1.
} 
The Heidelberg Report recommendation on the widening of the scope of the EIR was taken up by the Commission, and now appears in the final text of the recast EIR, as published in June 2015. Article 1 of the recast EIR provides:

This Regulation shall apply to public collective ${ }^{118}$ proceedings, including interim proceedings, which are based on laws relating to insolvency and in which, for the purpose of rescue, adjustment of debt, reorganisation or liquidation:

(a) a debtor is totally or partially divested of its assets and an insolvency practitioner is appointed;

(b) the assets and affairs of a debtor are subject to control or supervision by a court; or

(c) a temporary stay of individual enforcement proceedings is granted by a court or by operation of law, in order to allow for negotiations between the debtor and its creditors, provided that the proceedings in which the stay is granted provide for suitable measures to protect the general body of creditors, and, where no agreement is reached, are preliminary to one of the proceedings referred to in point (a) or (b).

Where the proceedings referred to in this paragraph may be commenced in situations where there is only a likelihood of insolvency, their purpose shall be to avoid the debtor's insolvency or the cessation of the debtor's business activities.

Revised Article 1 goes on to provide that these procedures "are listed in Annex A". ${ }^{119}$ This is intended (when read together with new Recital 9) to ensure that the Annex A is treated as exhaustive, thus curing the drafting ambiguity in the original EIR: inclusion in Annex A will be determinative of the question of whether a national procedure falls within the scope of the EIR.

The Commission regards its work on the reform of the EIR as complementary to its work on national restructuring laws. At the time that it released the Recommendation, the Commission's expectation was that restructuring procedures of the kind proposed in its Recommendation would, if introduced by Member States, be eligible for inclusion within Annex A of the recast EIR, with the result that there would be automatic recognition of the extension of their effects throughout the $\mathrm{EU}^{120}$ - assuming, of course, they were commenced as main proceedings. ${ }^{121}$ Thus, as the Commission explained, a stay ordered in connection with such proceedings would be effective to prevent enforcement action by unsecured ${ }^{122}$ creditors in other Member States - action that could

\footnotetext{
118 "Collective proceedings" are defined in recast EIR Art. 2(1) to mean proceedings which include all or a significant part of a debtor's creditors, "provided that, in the latter case, the proceedings do not affect the claims of creditors which are not involved in them".

${ }^{119}$ See also the definition of "insolvency proceedings" in recast EIR 2015/848, Art. 2(4).

${ }^{120}$ Impact Assessment accompanying the Recommendation, supra $\mathrm{n} 71$, Section 2.5.

${ }^{121}$ Under the recast EIR it will also be possible for such proceedings to be commenced as secondary or territorial proceedings, thanks to the removal of the restriction that such proceedings be winding-up proceedings (see $\mathrm{n} 106$ above), but these proceedings are confined to local assets.

${ }^{122}$ The EIR (either in current or recast form) does not fully resolve the question of the ability of secured creditors to enforce against assets subject to security that are situated outside the Member State in which main proceedings are opened (see EIR recast Art. 8, providing that the opening of proceedings under the EIR shall not affect the rights in rem of creditors in relation to assets located in the territory of another Member State, with the result that this is left to the applicable law to determine, likely to be the lex situs). At best, the EIR offers the ability for secondary proceedings to be opened in any place of establishment. This may enable a stay to be imposed in those jurisdictions, where the law of the forum so provides: recast EIR 2015/848, Recital 68.
} 
otherwise imperil the achievement of a value-preserving restructuring. ${ }^{123}$ Similarly, any restructuring plan sanctioned within such a procedure "would be recognised and enforced in another Member State" under the EIR. ${ }^{124}$ Put together, then, the Recommendation and revised EIR are intended to ensure first the availability, in the national law of all Member States, of a procedure that facilitates the "efficient restructuring of viable enterprises in financial difficulty" (the Recommendation), and secondly the effectiveness of such procedures in cross-border cases by providing for their recognition and enforceability across the EU (the recast EIR).

Three points should be emphasised about the relationship between the EIR and the Recommendation. The first is that it is not entirely obvious that restructuring proceedings of the kind contemplated by the Commission would necessarily satisfy the eligibility criteria in revised Article 1 (as extracted above). This point will arise in the event that a Member State introduces a restructuring procedure designed in conformity with the Recommendation, and seeks its addition to the existing list of procedures in Annex A of the recast EIR. Unlike the original EIR, ${ }^{125}$ there is no provision within the recast EIR for the amendment of its annexes, with the apparent result that a legislative process will be required for such an amendment ${ }^{126}$ - at which point in time, presumably, conformity with the eligibility criteria in Article 1 would be scrutinised.

The requirement of recast Article 1(1) that the proceedings to which the EIR applies be "based on a law relating to insolvency" does not appear problematic. The recitals to the recast Regulation indicate that this is intended to exclude procedures that are not designed "exclusively" with insolvency situations in mind (recast EIR Recital 16). Thus, the recitals explain, a procedure that is accessible at some pre-insolvency stage could fall within the scope of the EIR, provided that its purpose is to assist debtors - for whom insolvency is already a "real and serious threat" (recast EIR Recital 17) - in avoiding insolvency. ${ }^{127}$ There is an obvious synergy between these provisions and the text of the Recommendation, which is concerned with procedures designed to enable debtors already in "financial difficulties" (such that there is a "likelihood of insolvency") to avoid insolvency by restructuring. ${ }^{128}$ Thus, a stand-alone procedure of the kind envisaged in the Recommendation would satisfy this aspect of Article 1, while a national procedure that facilitates the restructuring of corporate debt and/or equity but was not designed "exclusively" with insolvency in mind - such as the English scheme of arrangement ${ }^{129}$ - appears not to qualify. Other aspects of Article 1(1) are more difficult. Proceedings should be "public" and "collective" (defined to mean proceedings which include all or a "significant" proportion of creditors,

\footnotetext{
${ }^{123}$ Impact Assessment accompanying the revision of the European Insolvency Regulation, supra n 23, Section 3.2.1.

${ }^{124}$ Impact Assessment accompanying the Recommendation, supra n 71, Section 2.5.

${ }^{125}$ See Article 45 EIR 1346/2000.

${ }^{126}$ F.M. Mucciarelli, 'Private international law rules in the Insolvency Regulation Recast: a reform or a restatement of the status quo?' (University of London, Centre for Financial \& Management Studies Working Paper Series No. 125, 2015): "under the Insolvency Regulation Recast, Annexes can only be amended by ordinary legislative proceeding, which makes the system more rigid and not able to adapt to evolution of Member States' laws promptly", p. 9.

127 "their purpose shall be to avoid the debtor's insolvency or the cessation of the debtor's business activities": Art. $1(1)$.

${ }^{128}$ RR No. 6(a) and Recital 1: text to $\mathrm{n} 78$ above.

${ }^{129}$ There is no solvency criteria associated with the use of the scheme of arrangement procedure (Payne, supra $\mathrm{n} 37$, at pp. 176-178). The procedure does not appear in Annex A of the recast EIR 2015/848. As to the use of schemes for debt restructuring, see also n 15 above.
} 
provided that the proceedings do not "affect" the claims of creditors not involved $)^{130}$, and ones in which "the assets and affairs of a debtor are subject to control or supervision by a court" or "a temporary stay of individual enforcement proceedings is granted by a court or by operation of law". ${ }^{131}$ Taking the latter requirement first, the proceedings contemplated by the Commission may or may not feature a stay (the Commission recommending against an automatic stay, but allowing the court to impose one in its discretion), and the court has a very limited role while the plan is being negotiated (apparently limited to determining applications for the imposition of a stay or the (discretionary) appointment of a supervisor to scrutinise the conduct of managers). ${ }^{132}$ Similarly, the Commission's restructuring proceedings may or may not be "collective", since the Commission recommends that its procedure be made available to restructure a portion of liabilities (provided others are not "affected") 133 , and does not require this proportion to be "significant". It may be that the mere possibility that proceedings will exhibit these features will be sufficient to warrant the inclusion of a national restructuring procedure in Annex A. ${ }^{134}$ This would not, however, appear to resolve the question of whether a procedure of the kind contemplated by the Commission can be characterised as "public". The Recommendation contemplates restructuring proceedings that are initiated quietly, without a court order, so as to minimise publicity that may impact adversely on business continuity. The recitals to the recast EIR indicate that it is intended to apply only to proceedings "the opening of which is subject to publicity" so as to enable inter alia creditors to challenge jurisdiction to open. ${ }^{135}$ It seems difficult to characterise the Commission's restructuring proceedings as "public" in this sense, at least early on. There is also a related difficulty around when such proceedings, assuming they can fall within the EIR's scope, are to be considered "opened", given the limited role of the court (and the apparent absence of publicity) in these early stages. This would need to be clarified in national law, for it is the "opening" of Annex A proceedings that enlivens the EIR's operation.

The second point about the relationship between the EIR and the Recommendation relates to the position of secured creditors. The EIR provides that the opening of main proceedings "shall not affect" the rights in rem that creditors have over assets of the debtor that are situated in Member

\footnotetext{
${ }^{130}$ Recast EIR 2015/848, Art. 2(1). Recital 14 indicates that where proceedings do not encompass all creditors, they should be ones aimed at the rescue of the debtor.

${ }^{131}$ Provided that the proceedings provide for suitable measures to protect the general body of creditors, and - where no agreement is reached between the debtor and its creditors - that the proceedings are preliminary to either the divestment of the debtor and appointment of an insolvency practitioner, or the control or supervision of assets and affairs by a court: Art. 1(1)(c). The other option in Article 1, viz. proceedings in which the debtor is totally or partially divested and an insolvency practitioner appointed, will not be applicable to restructuring procedures of the kind contemplated by the Commission.

${ }^{132}$ Recital 10 suggests however that the requirement of court 'control' should be interpreted liberally, such that the mere possibility of court intervention in the debtor's assets and affairs through the imposition of a stay or appointment of a supervisor may suffice.

${ }^{133}$ RR No. 20 and above, text to $n 91$.

${ }^{134}$ One consequence of this approach will be that provisions of the EIR that assume general characteristics of the proceedings will have to be read down where the particular proceedings in issue do not exhibit these characteristics: thus, for example, the requirement that creditors return that which they have received by pursuing enforcement action in Member States other than that in which main proceedings are opened (Art. 20 EIR 1346/2000; Art. 23 recast EIR 2015/848) will presumably be interpreted in the context of quasi-collective restructuring proceedings to apply only to creditors intended to be affected by the proposed plan (see Veder on Art. 23 in van Zwieten and Bork n 97).

${ }^{135}$ Recital 12 recast EIR 2015/848; see also Recital 13, expressly excluding “confidential” proceedings from the scope of the Regulation. As to a challenge to jurisdiction to open, see Art. 4.
} 
States other than the state in which the proceedings are opened. ${ }^{136}$ Although there is no consensus as to the proper interpretation of this provision, ${ }^{137}$ several commentators have suggested that one of its effects is to prevent relevant secured creditor claims (i.e. claims secured by rights in rem over assets situated in Member States other than the state in which proceedings were opened) from being effectively compromised in main proceedings, so as to prevent a secured creditor from enforcing against secured assets abroad as if their claim had not been compromised. ${ }^{138}$ If this interpretation is the right one - and there is some basis for thinking that the provision was intended to so operate ${ }^{139}$ - then the protection afforded by the EIR to the holders of rights in rem could seriously impact on the prospects of achieving a restructuring of secured debt in such proceedings. ${ }^{140}$ Paradoxically, this aspect of the design of the EIR may actually make it more difficult to achieve a restructuring than if proceedings fell outside the scope of the EIR, for in such circumstances national law may at least provide mechanisms to restrain local secured creditors from attempts to enforce against secured assets abroad as if their claim had not been restructured. ${ }^{141}$

The third and final point about the interrelationship between the EIR and the Recommendation is more basic. The EIR is designed to resolve the coordination problems that arise in cross-border cases by restricting the jurisdictions where insolvency or restructuring proceedings can be opened, and by regulating the effects of those proceedings that are permissibly opened. The effectiveness of this strategy clearly depends on the effectiveness of the underlying insolvency or restructuring procedures - that is, the procedures supplied by national law. If, for example, "main" restructuring proceedings opened under the EIR are slow or otherwise value-destructive, or are able to be used oppressively by one constituency to extract value at the expense of others, then bringing such proceedings into the modified universalist framework of the EIR - under which recognition and extraterritorial effects are effectively assured, and the opening of rival proceedings is restricted - is less attractive. Put another way, the inclusion of a procedure within the scope of the EIR could be predicted to enhance the effectiveness of a well functioning procedure, and to exacerbate the costliness of a poorly functioning procedure. Thanks to the efforts of the Commission, the EIR has been widened so as to permit the addition of debtor-inpossession debt restructuring procedures to Annex A. It is therefore particularly important to

${ }^{136}$ EIR 1346/2000 Art. 5; recast EIR 2015/848 Art. 8. These provisions are expressed to apply to all 'insolvency proceedings' opened under the EIR, but only main proceedings encompass assets situated outside the Member State where proceedings where opened.

${ }^{137}$ See the literature review in B. Wessels, International Insolvency Law (3 ${ }^{\text {rd }}$ ed., Deventer, Wolters Kluwer 2012), [10635].

${ }^{138}$ G. Moss, I. Fletcher and S. Isaacs (eds.), The EC Regulation On Insolvency Proceedings: A Commentary and Annotated Guide (2nd ed., Oxford, OUP 2009), [6.138]; Wessels, ibid [10658]; see also the tentatively expressed view of the reporters in the Heidelberg Report, supra $\mathrm{n}$ 109, at pp. 282-283; cf K. Pannen (ed.), European Insolvency Regulation (Berlin, De Gruyter 2007), Art. 5 para. 28.

${ }^{139}$ As Moss, Fletcher and Isaacs note (ibid [6.56]), Manfred Balz - who was the chairman of the working group that produced the 1995 convention on which the EIR 1346/2000 was based - wrote at the time of drafting that this provision was expected to prevent such secured creditors from being "impaired by a plan": M. Balz, "The European Union Convention on Insolvency Proceedings', 70 Am. Bankr. L.J. (1996), 485, 509.

${ }^{140}$ The opening of secondary restructuring proceedings (under which a parallel, mutually dependent, restructuring plan is negotiated) is one possible solution, but this will involve significant direct costs, and will in any case not be possible (wherever the secondary proceedings fall within the scope of the EIR) if the debtor does not have an establishment in the place in which the assets are located. As Moss, Fletcher and Isaacs note, a contractual solution to this problem might be negotiated ex ante between a class of secured creditors: supra n 138, at [6.138].

${ }^{141}$ See Moss, Fletcher and Isaacs, supra n 138, reasoning that the issue of such an injunction would be contrary to Art. 5 of the EIR 1346/2000; Virgos and Garcimartin, supra n 101, at [162]. 
ensure that these procedures are properly designed. In the next section, we evaluate whether the Commission's Recommendation is likely to result in optimally designed restructuring procedures.

\section{Evaluation of the Restructuring Recommendation}

The RR of the European Commission can be evaluated from different perspectives. First, the question can be raised whether harmonising Member States' restructuring laws as opposed to establishing or strengthening regulatory competition in this area is a sensible policy objective, and - if so - how this harmonisation can best be achieved. Second, the scope of the Commission's harmonisation agenda can be questioned, with reference to the interaction between the Commission's proposed restructuring procedure and existing national insolvency laws. Third, the substantive recommendations for the design of Member States' restructuring laws need to be scrutinised. In the following, we will examine each of these issues in turn.

\section{Harmonising Member States’ Restructuring Laws}

If a specific national restructuring regime is less efficient than another, the Member State concerned has an incentive to modernise its domestic restructuring laws. However, that in itself is not a sufficient reason for harmonising Member States' restructuring laws on the European level. As a European policy, harmonising Member States' restructuring regimes is not without alternatives: the European Commission could also promote or strengthen regulatory competition between the Member States with respect to their domestic restructuring regimes.

However, the Commission rightly chose not to pursue this alternative regulatory approach. It is true that regulatory competition with respect to restructuring regimes has certain benefits in terms of searching for new and efficient restructuring laws (competition as a "discovery procedure"142 $).{ }^{143}$ At the same time, negative effects for stakeholders that lack the means to actively pursue or influence restructuring arbitrage, such as non-adjusting creditors ${ }^{144}$ in particular, cannot be excluded. ${ }^{145}$ In addition, as already mentioned above (see Section I), restructuring arbitrage via COMI shifts is expensive and does not pay for SMEs. The same holds true, albeit to a lesser degree, for such arbitrage without a COMI shift. Further, regulatory competition and a multitude of different national restructuring regimes imply fewer (positive) network effects that could be associated with legal harmonisation. ${ }^{146}$ Finally, the EIR explicitly aims at excluding forum shopping and regulatory competition (Recital 4), and the current reform

\footnotetext{
${ }^{142}$ F.A. Hayek, 'Der Wettbewerb als Entdeckungsverfahren' in Internationales Institut "Österreichische Schule der Nationalökonomie" (ed.), Die Österreichische Schule der Nationalökonomie: Texte - Band II von Hayek bis White (Manz, Vienna 1968), pp. 119 et seq.

${ }^{143}$ H. Eidenmüller, 'Abuse of Law in the Context of European Insolvency Law', 6 ECFR (2009), 1, 6 et seq.

${ }^{144}$ See L. Bebchuk and J. Fried, 'The Uneasy Case for the Priority of Secured Claims in Bankruptcy', 105 Yale L.J. (1996), 857.

${ }^{145}$ Eidenmüller, supra $\mathrm{n} 143$, at 6 et seq.

${ }^{146}$ See M. Klausner, 'Corporations, Corporate Law and Networks of Contracts', 81 Va. L. Rev. (1995), 757, 789 et

seq.; F. Gomez and J. Ganuza, 'An Economic Analysis of Harmonization Regimes - Full Harmonisation, Minimum Harmonisation or Optional Instrument?', 7 ERCL (2011), 275, 281; H. Eidenmüller, 'What can be wrong with an option? An optional Common European Sales Law as a regulatory tool', 50 CMLR (2013), 69, 70 et seq.; A. Engert, 'Networks and Lemons in the Market for Contract Law', in H. Eidenmüller (ed.), Regulatory Competition in Contract Law and Dispute Resolution (Munich, C.H. Beck 2013), pp. 304 et seq.
} 
is not going to change that (new Recitals 5, 29-31). ${ }^{147}$ Hence, the regulatory environment in Europe is not geared towards regulatory competition in the field of restructuring laws. ${ }^{148} \mathrm{In}$ pursuing a harmonisation strategy, the European Commission acts in line with its prior policies: harmonisation of jurisdictional and private international insolvency law rules is followed by harmonisation of substantive insolvency law rules.

Once the case for harmonisation is accepted in principle, a secondary question arises as to the mode through which this could best be achieved. In the Recommendation, the Commission adopts a "minimum standards" approach, under which Member States are simply encouraged to ensure that their restructuring law exhibits at least the core features the Commission has prescribed. As the discussion in Section II 3 above makes clear, the result of this is that many design aspects of the restructuring procedures are left to Member States to determine. These include the way "likelihood of insolvency" is to be defined (as one of the core criteria for use of the procedure (RR No. 6(a)), ${ }^{149}$ the majority requirements that must be fulfilled for a restructuring plan to be eligible for court sanction so as to become binding (RR No. 18), the rules on how classes of creditors are to be constituted, ${ }^{150}$ whether or not provision is to be made for a cramdown of classes (such that a majority of classes can bind a minority), ${ }^{151}$ the impact of the stay on ongoing proceedings, ${ }^{152}$ the treatment of executory contracts, liabilities incurred under new contracts and of new finance obtained during the negotiation of the restructuring plan, ${ }^{153}$ and the extent to which the restructuring plan is vulnerable to subsequent avoidance under insolvency or company law transaction avoidance rules. ${ }^{154}$ The design of these aspects of restructuring procedures will clearly be fundamental to their functionality in practice. The result of leaving this to Member States is that there will be divergences in design choices. What is more, the RR only aims at providing for minimum standards as an interim strategy, but it is completely unclear what "further" harmonisation with respect to a specific regulatory problem could or would mean. The overall result is likely to be quite far from a "harmonised" position - with the consequence that debtors may continue to suffer from an "uneven playing field" when it comes to the prospects of achieving a value-preserving restructuring in financial distress. Taken together, then, the gaps and undefined concepts in the RR and its (mere) minimum harmonisation approach leads one to conclude that harmonisation benefits resulting from an implementation of the RR in the Member States would be very limited indeed, even assuming that the minimum standards selected by the

\footnotetext{
${ }^{147}$ Indeed, the new provisions on the relaxing of the COMI presumptions are explicitly designed to restrict debtors' ability to forum shift in the lead up to the commencement of proceedings that fall within the scope of the EIR (Recital 31 and Art 3(1) recast EIR 2015/848), though the restriction is a limited one in that it remains open to a debtor to prove that their COMI has been moved.

${ }^{148}$ However, it has already been mentioned that not all of the Member States' pre-insolvency proceedings will, after the reform of the EIR enters into force, be within the scope of the regulation (see Sections I and III). They must be based on a law relating to insolvency, and they must be included in Annex A. This is not the case, for example, with respect to an English SoA. Hence, regulatory competition with respect to restructuring regimes will continue to be part of the regulatory landscape in Europe, albeit only to a limited extent.

${ }^{149}$ Text to $\mathrm{n} 78$ and below, Section IV 3(c).

${ }^{150}$ On the latter issue, RR No. 17 only stipulates that creditors with different interests should be treated in separate classes and that, at a minimum, there should be separate classes for secured and unsecured creditors. As is wellknown, the rules on group formation are in practice very important and litigation-prone. Against this background, it is surprising how little normative guidance No. 17 provides.

${ }^{151}$ Text to $\mathrm{n} 94$ and below, Section IV (3)(b) (4).

152 Section II 3(4) above.

${ }^{153}$ Section II 3(4) and below, Section IV 3(c).

${ }^{154}$ See Section II 3(6) (the Commission's Recommendation dealing only with the application of transaction avoidance law to new finance provided for in a plan), and sub-section (2) immediately below.
} 
Commission are the right ones (sub-section (3) below). Had the European Commission really aimed to take significant step towards harmonisation, it would have had to regulate on many more of the issues raised by pre-insolvency company restructurings, and in more depth.

\section{The Scope of the Commission's Harmonisation Project}

All Member States presently have one or more existing procedures to which a distressed business debtor may become subject. The number of such procedures, the criteria for their initiation (including whether and under what circumstances mandatory filing is required), the impact of their initiation on managers, creditors and other stakeholders, and the outcomes that they may permit or prescribe for the business (break-up; auction on a going concern basis; reorganisation) will vary from Member State to Member State. The RR is silent on these procedures and, assuming their persistence (as the Commission appears to do), for the most part silent on their interaction with restructuring procedures of the kind contemplated by the Commission. The two exceptions to this are (i) the Commission's recommendation that providers of new finance extended under a sanctioned restructuring plan be insulated from the later application of national transaction avoidance rules and personal liability rules (except in cases of fraud), ${ }^{155}$ and (ii) the recommendation that a stay ordered within the Commission's restructuring procedure should have the effect of "suspending" the operation of mandatory filing rules, and suspending applications by creditors for the commencement of insolvency proceedings. ${ }^{156}$ Apart from these two recommendations, the Commission essentially approaches restructuring law in isolation - in stark contrast to the harmonisation agenda sketched out by INSOL Europe and the European Parliament in 2010-2012, which encompassed various aspects of insolvency and restructuring law. $^{157}$

There are a number of risks associated with this approach. The first is that the procedures about which the Recommendation is largely silent - i.e. procedures that do not exhibit the features specified by the Commission - may have an adverse impact on the ability of a financially distressed debtor to restructure, either within or outside the auspices of the formal law. Thus, for example - as the Commission itself appeared to acknowledge in its 2012 Communication ${ }^{158}$ mandatory filing rules may propel a debtor into a formal insolvency procedure at a point in time when an informal restructuring (i.e. a workout) could have been achieved outside the auspices of the formal law at less cost. The Commission's recommendation that such mandatory filing rules be "suspended" if a stay is ordered to facilitate restructuring is not a solution to this problem: the relief offered by this recommendation arises only after a stay is applied for and imposed (offering no protection to the debtor in the period preceding this), and in any event requires the debtor to have recourse to a formal restructuring procedure of the kind contemplated by the Commission thus steering the debtor away from a workout. Other national insolvency law rules may also have an adverse impact on the preparedness of debtors, creditors or counterparties to participate in a restructuring. Thus, for example, uncertainty about the later application on the liability of directors or the avoidance of transactions in relation to behaviour or transactions entered into in the period leading up to the sanctioning of a restructuring plan may have a chilling effect on the willingness of debtors, creditors or counterparties to participate. The Commission is generally silent on the interaction between these rules and its restructuring procedure, making a

\footnotetext{
${ }^{155}$ RR No. 27 and above, Section II 3(6).

${ }^{156}$ RR No. 12 and above, Section II 3(4).

${ }^{157}$ Text to nn 47 et seq.

${ }^{158}$ Text to $\mathrm{n} 64$.
} 
recommendation only in relation to the position of new financiers (and even there, only in relation to finance provided as part of the terms of a sanctioned plan). If the Commission's goal of facilitating restructurings is to be taken seriously, then the interactions between national restructuring and insolvency law rules must be more fully and carefully explored.

The second risk of the Commission's approach is that it may lead Member States to focus on facilitating restructuring at the expense of considering other means by which the legal system can preserve the value of financially distressed debtors - for example, by facilitating a quick auction. As explained above, in general, auctions to third parties are likely to be less costly to achieve, because they do not require bargaining with creditors to obtain a restructuring of liabilities. ${ }^{159}$ Whilst restructurings might be considered the most appropriate vehicle for value preservation in times of crisis or when the company owns "dedicated assets" (see Section II 2 above and Section IV 3(a) below), ${ }^{160}$ the Commission is not advocating the introduction of temporary crisis management restructuring tools - rather, it advocates the introduction of formal procedures to the statute books of Member States, procedures that will (unless and until repealed) be available in good times as well as bad ${ }^{161}$ and regardless of the circumstances of an individual case. As a consequence, Member States must think carefully about how they can ensure that auctions are facilitated in circumstances where these would be more likely to preserve value. This protection would need to be 'built in' to a stand-alone restructuring procedure (so as to allow an exit to facilitate an auction) of the kind the Commission appears to be positing. The Recommendation suggests that the Commission has not yet fully grappled with this: as noted above, it recommends that a stay be ordered under its restructuring procedure where a significant number of creditors (by value) support the negotiations, and the plan has a "reasonable prospect of being implemented and preventing the insolvency of the debtor" (RR No. 11). But if (as is recommended) such a stay would bar the commencement of other procedures, including insolvency procedures in which an auction could be achieved, then what should be determined is not only if the restructuring plan has reasonable prospects of success and would prevent insolvency - but also whether restructuring (rather than an auction) would be more likely to be value maximising. The same question needs to be grappled with in Member States that resolve to offer a single procedure in which either outcome - reorganisation or auction - is a possibility: a filtering mechanism must be designed to promote value-maximisation in the making of the choice between outcomes.

In summary, the European Commission's exclusive focus on restructuring proceedings carries with it at least two significant risks: first, it fails to give full treatment to issues arising from the interaction between Member States' formal insolvency laws and the restructuring mechanism proposed; second, it fails to provide for a mechanism that channels a financially distressed business towards the value maximising mechanism in an individual case - be that a restructuring, an auction or a liquidation.

\section{Substantive Recommendations for Member States’ Restructuring Laws}

That takes us to an analysis of the substantive recommendations contained in the Commission's proposal. A critical analysis of the RR's substantive recommendations for Member States' restructuring laws can only be undertaken on the basis of (sensible) policy goals with respect to

\footnotetext{
159 Text to $\mathrm{n} 69$.

${ }^{160}$ Text to nn 69 et seq.

${ }^{161}$ This is the Suarez and Sussman argument against the introduction of corporate reorganization procedures in crisis: see $\mathrm{n} 73$.
} 
reforms in this field. From such goals, the contours of an efficient DIP regime can be derived. Against this background, the content of the RR of the European Commission can be evaluated.

\section{a) Sensible Regulatory Goals}

From an economic perspective, restructuring a business and keeping it as a going concern is to be advocated only if the firm's going concern value exceeds its liquidation value, i.e. restructuring makes sense only in cases of financial but not economic failure of a business. ${ }^{162}$ Based on this criterion, the great majority of businesses that find themselves in financial distress in practice are also economically distressed and should be liquidated, not restructured. ${ }^{163}$ Whereas the RR notes that only "viable" businesses should be restructured (RR Nos. 1 and 16), this important filtering function of insolvency law is not reflected properly in the RR's rules. These rules appear to imply that firms in financial distress generally are "worthy" of being restructured, and there are no rules in the RR that would define exactly when a liquidation - or an auction - should be preferred and who is empowered to take this decision. The RR is geared towards restructuring financially distressed firms. This appears to overlook economic reality.

If a firm should be maintained as a going concern (because its going concern value exceeds its liquidation value), a sensible regulatory aim is to maximise the net asset value that, in principle, can be distributed amongst the firm's creditors. This implies three sub-goals. First, any restructuring efforts should be undertaken earlier rather than later. The earlier restructuring measures are implemented, the higher the (remaining) going concern value of the firm will be. Further, the incentive of shareholders and (to the extent their interests are aligned) managers to 'gamble' by pursuing high-risk, high-reward investment strategies at the expense of creditors becomes stronger the less equity is left in the firm, i.e. the later in time a restructuring is initiated. Triggering restructuring efforts earlier rather than later presupposes corresponding incentives for those best informed about the financial and economic status of the business. Usually this will be the firm's shareholders and/or managers. Whether appropriate incentives should be positive ('carrots') or negative ('sticks') is another matter. ${ }^{164}$ Second, maximising a firm's net asset value implies that the existing firm should be restructured only if this produces higher returns than a going concern asset sale. This may be the case, for example, because the legal entity that runs the firm "owns" dedicated assets such as favourable contracts, licenses, permits or tax loss carryforwards that cannot (easily) be transferred to a new legal entity. ${ }^{165}$ This may also be the case in a crisis situation in which there is no (efficient) market for firms sold in an auction. ${ }^{166}$ Third, maximising a firm's net asset value implies that - direct and indirect - bankruptcy costs should be minimised. ${ }^{167}$ This can be achieved with a quick, simple and, if possible, confidential

\footnotetext{
${ }^{162}$ See H. Eidenmüller, Unternehmenssanierung zwischen Markt und Gesetz (Cologne, Otto Schmidt 1999), pp. 31 et seq.; H. Eidenmüller, 'Reformperspektiven im Restrukturierungsrecht', 31 Zeitschrift für Wirtschaftsrecht (2010), 649,650 .

${ }^{163}$ H. Eidenmüller, 'Reformperspektiven im Restrukturierungsrecht' ibid.

${ }^{164}$ S. Franken, 'Creditor- and Debtor-Oriented Corporate Bankruptcy Regimes Revisited', 5 EBOR (2004), 645.

${ }^{165}$ See H. Eidenmüller (1999), Unternehmenssanierung zwischen Markt und Gesetz, supra n 162, at p. 33; G. Bitter and A. Laspeyres, 'Rechtsträgerspezifische Berechtigung als Hindernis übertragender Sanierung', 31 Zeitschrift für Wirtschaftsrecht (2010), 1157.

166 Text to nn 69 et seq. above.

${ }^{167}$ Direct bankruptcy costs are the costs of conducting bankruptcy proceedings such as fees of an insolvency administrator or court fees. Indirect bankruptcy costs comprise the loss of firm value because of its financial distress. These indirect costs usually are much higher than the direct costs. See R.A. Brealey, S.C. Myers and F. Allen,
} 
restructuring. However, the desirable degree of informality and/or confidentiality of the proceedings should also be determined by reference to other important goals that restructuring laws should respect.

Maximising a firm's net asset value is an important economic goal for the design of restructuring procedures. At the same time, however, such procedures must also contain safeguards against abuse by one stakeholder/constituency seeking to extract wealth at the expense of others. Such a wealth transfer does not necessarily have an impact on firm value. However, the (re)distribution is still problematic, except to the extent it is fully anticipated and fully priced ex ante - which it never will be. As a consequence, restructuring procedures would only be predicted to reduce investment costs ex ante if such oppression ex post could be controlled - which is why certain procedural safeguards are necessary, calling for some degree of formality, judicial review and transparency. There will of course also likely be public law/constitutional law rules that require such safeguards wherever the procedure allows dissenting creditors to be bound, for this amounts (at least in formal terms) to an expropriation of their property.

These are not just "academic" concerns. Restructuring practice in the US in the last two decades, in particular, shows the dangers that might be associated with the presence of highly professional financial investors within the creditor community. What appears, on the books, to be a procedure in which the debtor is in possession has shifted to become a central "power base" for

sophisticated and secured financial creditors - the "secured party in possession". ${ }^{168}$ It appears that the par conditio creditorum is threatened, company assets are depleted before a Chapter 11 filing, and such filings take place later than used to be the case historically. ${ }^{169}$ Reformers of restructuring laws must be cognisant of the risk of such negative effects, and they must seek to preserve and strengthen fundamental principles of (procedural) justice that aim to control abuse of the process by one stakeholder/constituency who seeks to extract wealth at the expense of others. ${ }^{170}$

To sum up: reforms of restructuring laws should respect the economic filtering function of insolvency law - firms should only be restructured if their going concern value exceeds their liquidation value. If a firm passes this test, then the goal should be to maximise the net asset value that could, in principle, be distributed to the firm's creditors. At times, a restructuring will maximise firm value, and in a different setting, an auction will be the preferred route. In addition, restructuring laws should be designed to respect and strengthen fundamental principles of (procedural) justice so as to help prevent wealth transfers from one creditor or stakeholder constituency to another.

\section{b) Features of an Efficient DIP Regime}

Against this background, the essential features of an efficient DIP regime that facilitates the restructuring of businesses in difficulties can be described as follows: ${ }^{171}$

Principles of Corporate Finance ( $10^{\text {th }}$ ed., New York, McGraw-Hill/Irwin 2011), pp. 478 et seq.; Eidenmüller, Unternehmenssanierung zwischen Markt und Gesetz, supra $\mathrm{n}$ 162, at pp. 75 et seq.

${ }^{168}$ D.G. Baird and R.K. Rasmussen, 'Chapter 11 at Twilight', 56 Stanf. L.R. (2003), 673; see also H. Eidenmüller, 'Die Eigenverwaltung im System des Restrukturierungsrechts', 175 Zeitschrift für das gesamte Handelsrecht und Wirtschaftsrecht (2011), 11, 19 et seq. with further references.

${ }^{169}$ Eidenmüller, ibid at 21.

${ }^{170}$ In the US, a special commission of the American Bankruptcy Institute (ABI) has recently reviewed the operation of Chapter 11 and suggested reforms, see http://commission.abi.org/.

${ }^{171}$ See Eidenmüller, 'Die Eigenverwaltung im System des Restrukturierungsrechts', supra n 168, at 29 et seq. 
(1) Most important is the regulatory goal of facilitating such restructurings only for firms that are presumptively economically viable. There are different routes to achieving this goal:

(a) Solvency declaration of firm. One regulatory possibility would be to require a firm that seeks to initiate the restructuring process to declare that it is not insolvent on a cash flow or balance sheet basis. This declaration would need to be certified by a competent expert such as an accountant or tax advisor. If the firm is not insolvent, it is not so severely financially distressed that its further operation is in serious doubt. At the same time, it is at least unlikely that the firm suffers from economic failure, i.e. it is likely that it is worth more alive than dead. Conversely, one should not expect that economically viable firms will abuse the procedure en masse for strategic reasons, e.g. to terminate disadvantageous contracts, reduce the workforce, etc. Given the direct and indirect bankruptcy costs that are associated with every insolvency or restructuring proceeding (costs that may severely reduce firm value), such cases will likely be the (rare) exception, not the rule. Further, abusive petitions in individual cases can be counteracted by the doctrine of abuse of law. ${ }^{172}$ According to this doctrine, abusive petitions are to be dismissed.

However, there are several serious downsides with this proposal. First, and most importantly, such a rule would render the restructuring procedure not very useful in a systemic/macro crisis where, as a result of an exogenous shock, firms are suddenly insolvent. Given that the RR has been explicitly designed as a crisis measure, this would run counter to an important regulatory goal. Apart from in times of crisis, there is also the objection that some forms of insolvency arise quickly - perhaps not in time for a debtor to file (imagine a firm that unexpectedly loses its main customer who accounted for $80 \%$ of the firm's regular and stable revenues). Second, while the effect of such a rule would presumably be to incentivise very early filings by debtors, it is not clear that this would always be value maximising - given that debtors may be able to negotiate a workout outside the auspices of the formal law. One should not force or even necessarily encourage an unnecessary use of the formal procedure. Third, the "solvency certificate" would come from an expert or professional commissioned by the debtor who is, therefore, not fully independent, and solvency is in any case clearly not a perfect proxy for economic viability.

(b) Procedural safeguards in the proceedings. An alternative regulatory approach could be to dispense with any solvency/insolvency requirement and instead design the restructuring procedure so as to make it highly likely that only viable firms will be able to use it. A restructuring plan will need creditor assent, and creditors will, acting in their own economic interests, be anxious to ensure that only economically viable firms obtain the benefit of a restructuring. Also, plan confirmation requirements can be designed such that no dissenting creditor receives less than if the firm were liquidated - which also supports the goal of restructuring only viable firms. Further, the benefit of a stay on creditor enforcement actions could be given only to firms that, upon examination by the competent court, fall into this category.

While such measures are certainly helpful to filter economically viable from non-viable firms, they have one significant downside: they kick in very late, i.e. after the whole "restructuring machinery" has already been set in motion and significant costs have been sunk in the process. Hence, an examination of this crucial issue very early on in the proceedings seems to be preferable.

(c) Opinion of court-appointed examiner/supervisor. An independent examiner could be appointed by the competent court immediately upon the filing of a petition to initiate a restructuring proceeding, and charged with the task of examining and certifying the economic viability of the petitioning firm. This would enable the filtering of viable from non-viable firms

${ }^{172}$ H. Eidenmüller, 'Strategische Insolvenz', 35 Zeitschrift für Wirtschaftsrecht (2014), 1197, 1201 et seq. 
very early on in the process through the use of an independent specialist who is supervised by the competent court. The examiner could also advise on whether a viable firm seeks to abuse the restructuring process in order to, for example, shift value from the firm's creditors to its shareholders (abusive petitions would need to be dismissed, see above). During the proceedings, the examiner/supervisor could also be tasked with other important functions such as monitoring the financial affairs of the debtor, see infra at (3).

(2) A second feature of an efficient DIP regime is that it gives the debtor firm certainty that the procedure will be conducted in DIP form, i.e. without appointment of an insolvency practitioner who would take over key managerial functions as soon as the firm files the petition to initiate the restructuring process. Only if this certainty is provided will the goal to motivate distressed firms to file in a timely fashion be achieved. Of course that does not guarantee the incumbent management's position upon or after filing: given that the filing firm usually will be cash-poor, financial creditors will have leverage to initiate changes in top management positions such as, for example, by appointing a CRO, and experience shows that they use this leverage if needed. ${ }^{173}$ Under these circumstances, a legal displacement mechanism that would charge the competent court with performing this displacement function seems to be unnecessary. Hence, if the debtor firm files a petition to open restructuring proceedings in DIP form, such proceedings should be opened straight away without any interim or preliminary proceedings. ${ }^{174}$ There is no need for interim or preliminary proceedings because it is not necessary for the competent court to examine the financial status of the firm, in particular whether it is insolvent or not. Given that the proceedings are always conducted in DIP form, the debtor has a certain expectation to stay in charge in terms of exercising core management functions during the process. ${ }^{175}$ However, the fiduciary duties of the debtor's officers in the process should shift from its shareholders to its creditors at least once the firm is insolvent.

(3) Third, and differing from US law, the DIP restructuring proceeding should always lead to an appointment of a supervisor by the competent court. His or her task would be to examine the economic viability of the petitioning firm (see supra at (1)(c)). More generally, he or she would have to safeguard the interests of all creditors (or at least those with an economic interest in the firm ${ }^{176}$ ) in the process. Appointing such a supervisor is necessary to make sure that fundamental principles of (procedural) justice are observed. A neutral third party is needed to prevent the par conditio creditorum from being undermined prior to the petition or during the process by dominant financial creditors. Given that the supervisor's role would not be to take over the management of the firm, the costs associated with the appointment of such a supervisor should be limited.

\footnotetext{
${ }^{173}$ K.M. Ayotte and E.R. Morrison, 'Creditor Control and Conflict in Chapter 11', 1 Journal of Legal Analysis (2009), 511.

${ }^{174}$ This implies that there are no further requirements for the initiation of restructuring proceedings such as, for example, that creditor interests are not negatively affected by the process. Creditor interests are safeguarded by the obligatory appointment of an examiner/supervisor, see in the text supra and infra.

${ }^{175}$ Assuming that a debt-to-equity swap can be forced upon the incumbent shareholders in the proceedings (see in the text infra at (4)), it could be argued that this might reduce their incentives for an early filing. However, such swaps are relevant in restructuring practice primarily with respect to large (listed) public corporations and, with respect to such firms, management typically has greater autonomy in conducting the firm's affairs than in a small closely held corporation (see, for example, $\S 76$ para. 1 of the German Stock Corporation Act). Moreover, the US restructuring practice under Chapter 11 does not suggest that filings are delayed because shareholders fear that they lose their equity stake in the process.

${ }^{176}$ This includes the difficult determination, to be taken in the proceedings, of which creditors are above water / not out of the money.
} 
(4) Fourth, if the purpose of the DIP regime - or one of its purposes - is to facilitate the achievement of a binding restructuring plan, then in addition to making provision for dissenting creditors of one class to be bound by a majority in that class, the procedure should provide for one of two things: (i) The ability to bind not only creditors but also members to the plan, since adjustments in the rights of creditors are likely to be conditional on some adjustments to member rights. This requires a cram-down power for the competent court, because otherwise the plan negotiations and the plan adoption process will be severely impeded by attempts to secure the majority consent of each affected class. (ii) Alternatively, there needs to be an ability to enable the transfer of the business to a newly incorporated entity along with select (restructured) liabilities. This is functionally equivalent to a cram-down, since it enables those 'out of the money' to be left behind. ${ }^{177}$ If, under the applicable laws, dedicated assets cannot be transferred to a new legal entity and these assets are needed for a value-maximising restructuring, route (i) will be the preferred alternative. Of course, the rules for plan adoption need to contain rigorous controls against oppression, since either case results in those adjudged out of the money being sidelined. These controls should include guaranteeing each affected stakeholder (creditor/shareholder) at least what he or she could expect to receive in a liquidation or auction or other form of disposal of the firm's assets - whatever the relatively best alternative mechanism is under the circumstances in the individual case. The rules on plan adoption should also provide for a streamlined voting mechanism on pre-packaged plans.

The four cornerstones for an efficient DIP regime put forward above must of course be complemented by additional and detailed rules. There has to be some provision made for the treatment of executory contracts (including ipso facto clauses) and new finance in the period while proceedings are pending (i.e. before the plan is sanctioned), for example. A more difficult question is whether there should always be an automatic stay that protects the debtor firm against enforcement actions by creditors and similar measures. As an instrument of restructuring policy, a stay can be justified even though the debtor is not necessarily insolvent (see above): because of backward induction, creditors find themselves in a prisoners' dilemma situation even before material insolvency of their debtor, leading to enforcement actions that might unnecessarily dissipate firm value. ${ }^{178}$ Further, a stay can be justified as a measure that curtails the leverage of informed and sophisticated creditors stemming from the threat of enforcement action to extract gains relative to less well informed/sophisticated creditors. ${ }^{179}$ Abusive filings by debtors that seek to force an unnecessary restructuring can be controlled by the examination process upon filing, see at (1)(c) supra. ${ }^{180}$ The stay should be time limited - e.g. for six months - with the possibility of an extension by the competent court for another six months on the basis of an application demonstrating the special circumstances of the case.

In short, an efficient DIP regime implies an immediate opening of the proceedings upon the petition of a debtor that is economically viable but in need of being restructured. The regime should always lead to the appointment of an examiner/supervisor that is tasked with safeguarding

\footnotetext{
${ }^{177}$ Paterson, supra $\mathrm{n}$ 43, at 15.

${ }^{178}$ See H. Eidenmüller, 'Trading in Times of Crisis: Formal Insolvency Proceedings, Workouts, and the Incentives for Shareholders/Managers', 7 EBOR (2006), 239, 242 et seq.

${ }^{179}$ It is true that quite often, creditors now have another form of exit through the distressed debt market (see Paterson, supra $\mathrm{n} 43$ ). However, this exit route will not always be available, especially not with respect to SMEs.

${ }^{180}$ One can raise the question whether cornerstone $(1)(\mathrm{c})$ is necessary if there were no stay. Do we then need to worry about the abuse of the procedure by non-viable firms? The managers of this kind of firm do not appear to have much leverage if creditors aren't stayed, and restructuring negotiations will presumably be shortlived if creditors just decline to participate. However, even in the absence of a stay, initiating formal restructuring procedures will usually give firms some bargaining leverage, i.e. via mobilising public opinion to support 'value destruction' by layoffs etc.
} 
the interests of all creditors in the process. Further, it should contain a cram down power for the competent court (or a functionally equivalent business transfer power), rules on executory contracts and an automatic stay.

\section{c) Evaluation of the Recommendation's Proposals}

Against this background, the main elements of the Commission's proposals in its RR can be critically analysed. The first point to note is the Commission's approach of tying the initiation of the process to some - undefined - likelihood of insolvency of the debtor firm (RR No. 6 (a)). With respect to inducing early restructurings, requiring firms to be in dire financial straits before they can initiate a formal restructuring process is counterproductive. As argued above, it should suffice if the petitioning firm is economically viable and is not abusing the process to shift value from its creditors to its shareholders. Both checks should be carried out by an examiner appointed by the competent court upon the filing of the restructuring petition. Hence, a likelihood of insolvency - however that is precisely defined - should not be a requirement for initiating a (formal) restructuring proceeding. ${ }^{181}$ As a consequence, such a restructuring proceeding would probably not fall within the scope of the recast EIR (see Section III supra). That does not marshall against the approach advocated here. Rather, the European Commission should consider a more fundamental reform of Article 1 EIR in due course. As has been shown, the revised Article 1 creates a lot of legal uncertainty that can only be tolerated by making Annex A determinative - which is unsatisfactory at least on a conceptual basis, and in any case may not be a panacea when it comes to making future amendments to Annex A. ${ }^{182}$

The second crucial weakness of the Commission's RR is that the appointment of a mediator or a supervisor "should not be compulsory" (RR No. 9). The competent court is supposed to appoint a supervisor on a case-by-case basis only "where it considers such appointment necessary". ${ }^{183}$ The RR severely underestimates the potential abuse of restructuring processes by firms that are either not economically viable or that seek to shift value from creditors to shareholders. The RR also underestimates the problem that has clearly become visible in the US reorganisation practice in the last two decades: sophisticated financial investors with a lot of clout undermine the par conditio creditorum pre-insolvency. A DIP regime without mandatory supervision by a neutral third party that is accountable to the whole creditor community and that performs crucial tasks on its behalf risks undermining fundamental principles of (procedural) justice. Any restructuring procedure should be conducted in the interest of all creditors (or at least those with an economic interest in the firm), and this can be assured only by a neutral person such as a court-appointed supervisor. Hence, a supervisor should always be appointed once a restructuring proceeding is initiated. His or her functions should be those described in Sections IV 3(b) supra.

A third crucial deficit of the Commission's RR lies in its minimalist approach to the role of the court in the restructuring process. The RR would like to have it all: a flexible and quick procedure

\footnotetext{
${ }^{181}$ A recent Commission discussion paper encouragingly suggests that the Commission may be moving away from imposing such a requirement. The discussion paper identifies twelve dimensions of the efficiency of restructuring frameworks, including the conditions for initiating the procedure. Its scoring system ranks jurisdictions with no solvency-related test for entry higher than jurisdictions that require proof of financial difficulties for entry: see $\mathrm{n} 17$ Table 2.1.

182 Text to nn 125-126 above.

${ }^{183}$ The RR envisions a mediator as a person that assists the debtor and creditors in the successful running of negotiations on a restructuring plan (RR No. 9 (a)). A supervisor is one who oversees the activity of the debtor and creditors and take the necessary measures to safeguard the legitimate interests of one or more creditors or another interested party (RR No. 9 (b)).
} 
with only minimal involvement of the competent court (see RR No. 7) and at the same time permit potentially massive curtailments of the claims of dissenting creditors with a minority protection standard that is not very clearly articulated (RR No. 22 (a) and (c)). This does not work: curtailments of creditor rights can only be justified if the legal standards for these curtailments are clearly defined and full court supervision and control are assured. One aspect of this is that the court should scrutinise class composition before a plan is voted on: in the Commission's procedure, the court appears to review the plan only at the time of sanctioning, after significant costs have already been sunk in its negotiation. ${ }^{184}$

Another important aspect of this concerns the position of those who are excluded from a restructuring plan. The RR contemplates a procedure in which a plan is negotiated with some creditors, while others are excluded from it. The Commission recommends that this be possible, provided that the creditors excluded from the plan are "not affected" by it (see, e.g., RR Nos. 22 (b) and 24). The word affected is not defined, but the Commission appears to mean that formal rights are not affected - that is, the creditor keeps his or her claim against the debtor. If so, there does not appear to be any control on the use of the process in conjunction with a sale procedure so that select restructured creditors are taken over to a new company, and other creditors are left behind. These other creditors do not have their formal rights affected, but there is now no asset that they can enforce against. This may be considered acceptable if they are undoubtedly 'out of the money' - but there should be a (judicially administered) safeguard to ensure that this is the case.

Further, the minority protection standard of the RR should be modified. The RR stipulates that the restructuring plan must not "... reduce the rights of dissenting creditors below what they would reasonably be expected to receive in the absence of the restructuring, if the debtor's business was liquidated or sold as a going concern, as the case may be ..." (RR No. 22 (c)). This is too generous a standard. Dissenting creditors must not be put into a position that is more likely than not to return them less than they would enjoy if the restructuring plan were not implemented. ${ }^{185}$ This alternative scenario might be a liquidation or a going concern sale, but this need not necessarily be so. A more demanding standard of this kind is also more likely to ensure due protection of property rights as enshrined, for example, in Article 1 of the Protocol to the ECHR: a dissenting creditor gets the full economic value of his or her right, as best as this can be assessed at the time of sanctioning.

Similar criticisms as regards curtailments of creditor rights can be raised with respect to the wideranging privileges foreseen by the RR for "fresh money" provided by DIP financiers in a restructuring plan (see RR Nos. 27 et seq.). Such privileges can only be justified if precisely defined legal safeguards are observed and full court supervision and control are in place. RR No. 22 (d) only stipulates that any new financing must be "... necessary to implement the plan and does not unfairly prejudice the interests of dissenting creditors." This standard is too vague. A better test could be modelled along the provisions on DIP financing in US Bankruptcy Code $\S 364 .{ }^{186}$ Conversely, the absence of provisions for the extension of new finance in the period between the commencement of the proceedings and the sanctioning of a plan, and for the treatment of executory contracts during this period (including ipso facto clauses), is also problematic.

\footnotetext{
${ }^{184}$ A recent Commission discussion paper appears to take the same approach, favouring limiting court involvement to the appointment of any insolvency practitioner and confirmation of a plan: $n 17$ Table 2.1.

185 "More likely than not" means a probability of greater than 0.5 in a scenario analysis.

${ }^{186}$ On these see, for example, C.J. Tabb, The Law of Bankruptcy (New York, Westbury 1997), pp. 788 et seq.; J. Parzinger, Fortführungsfinanzierung in der Insolvenz, (Munich, C. H. Beck 2013), pp. 81 et seq.
} 
In summary, the Recommendation should be criticised for requiring financial difficulties or a likelihood of insolvency as an entry test for the recommended restructuring proceeding. However, its main weakness is that it appears readily susceptible to abuse by sophisticated financial investors as a tool to enrich themselves at the expense of outside creditors and/or the debtor firm: it does not foresee the mandatory appointment of a supervisor, and it allows significant curtailments of creditor rights without sufficient legal safeguards.

\section{Summary and Outlook}

European restructuring laws are undergoing significant changes. The jurisdictional and private international law framework of the EIR has been revised, leading to a wider scope for the Regulation, better coordination between main and secondary proceedings, and new rules on insolvencies affecting multiple entities in a corporate group structure. In the meantime, the substantive rules for restructuring businesses in distress have also caught the attention of the European Commission. On 12 March 2014, the Commission published a recommendation which calls upon the Member States to modernise their restructuring laws so as to ensure their compliance with the Commission's "minimum standards". This paper has critically reviewed the methodology, scope and substance of the Recommendation, and explored aspects of its interaction with the EIR, and existing Member State insolvency laws. The main results can be summarised as follows:

1. The RR of the European Commission aims at maximising the net asset value of a firm in distress and attempts to achieve this aim by facilitating an early intervention that restructures the firm financially and thereby reduces or eliminates the risk of insolvency. The Commission argues that existing differences between the Member States' restructuring laws are an impediment to the effective functioning of the internal market. That line of reasoning is, in principle, convincing. At present, firms in different Member States have different opportunities to access efficient restructuring proceedings - either domestically, or by engaging in forum shopping (COMI shifts) or migration-less restructuring arbitrage. However, while its push towards harmonising Member States' restructuring laws is to be preferred to policy alternatives such as regulatory competition, the harmonisation proposed by the RR is sketchy - important issues are not dealt with, and important concepts are not defined. Espousing "minimum standards" rather than full (maximum) harmonisation is suboptimal, because the harmonisation level that can thereby be achieved is unlikely to resolve the current enormous diversity of restructuring laws in the Member States. In this respect, the Commission's recent announcement ${ }^{187}$ that it will now move to propose stronger harmonisation in the form of a legislative instrument is an encouraging development.

2. The recast EIR and the RR do not appear to dovetail perfectly. It is not entirely obvious that restructuring proceedings of the kind contemplated by the Commission would necessarily satisfy the eligibility criteria in revised Article 1 EIR. Additionally, where Member State restructuring proceedings are included in Annex A (and thereby fall within the Regulation's scope), their efficacy in restructuring cases may be somewhat undermined by the EIR's strong protection for rights in rem over assets situated in Member States other than the state in which proceedings are opened.

3. The European Commission's recent focus on restructuring proceedings carries with it at least two significant risks: first, it loses sight of the interactions between the Member States' formal insolvency laws - including filing and liability rules - and the restructuring mechanism proposed; second, it fails to provide for a mechanism that channels a financially distressed business towards

\footnotetext{
${ }^{187}$ n 27.
} 
the value maximising mechanism in an individual case - be that a restructuring, an auction or a liquidation. These points should be carefully considered by the Commission in setting the scope of its proposal for a legislative instrument for harmonisation of Member State laws.

4. a) Reforms of restructuring laws should ensure appropriate economic filtering: firms should only be restructured if their going concern value exceeds their liquidation value. If a firm passes this test, the goal should be to maximise the net asset value that could, in principle, be distributed to the firm's creditors. At times, a restructuring will maximise firm value, and in a different setting, an auction will be the preferred route. In addition, restructuring laws must be designed to respect and strengthen fundamental principles of (procedural) justice that help to prevent wealth transfers from one creditor/stakeholder (group) to another.

b) Against this background, an efficient DIP regime implies an immediate opening of the proceedings upon the petition of a debtor that is economically viable but in need of being restructured. The regime should always lead to the appointment of an examiner/supervisor that is tasked with safeguarding the interests of all creditors in the process. Further, it should contain a cram-down power for the competent court, rules on executory contracts and an automatic stay.

c) The Commission's RR can be criticised for requiring financial difficulties or a likelihood of insolvency as an entry test for the recommended restructuring proceeding. The main weakness of the RR, however, is that the procedure it contemplates appears susceptible to abused by sophisticated financial investors seeking to enrich themselves at the expense of outside creditors and/or the debtor firm: the RR does not foresee the mandatory appointment of a supervisor, and it allows significant curtailments of creditor rights without sufficient safeguards against oppression in place.

The RR invited the Member States to implement the Commission's recommendations within a year of its publication, i.e. by March 2015. It appears that the inclination of the Member States to accept this invitation has not been strong (to put it mildly) - large Member States such as the UK, France, Germany or Italy ${ }^{188}$ in particular have not reacted at all to the European Commission's initiative. A recent evaluation by the Commission of compliance with the Recommendation suggests that only two Member States (Slovenia and Hungary) have introduced reforms that resulted in Recommendation-compliant legislation (or at least partly compliant legislation). ${ }^{189}$ In some cases, this appears to be because Member States (rightly or wrongly) believe that their domestic laws already conform with the RR's principles and provide efficient pre-insolvency restructuring tools. ${ }^{190}$ Given the reform efforts that many Member States have undertaken in the last years under the pressure of regulatory competition and the financial and economic crisis, this does not appear to be an unreasonable reaction. In other cases, however, the Commission's evaluation indicates that some Member States do not have Recommendation-compliant laws, but have nevertheless not moved (at least as yet) to reform them: "a significant number of those which do not comply have not launched any reforms to date". ${ }^{191}$ Member States have not, of course, had much time to comply, and it may be that reforms are forthcoming. It may also be, however, that some Member States are reluctant to wholeheartedly embrace the restructuring recommendations of the European Commission, perhaps motivated the kind of serious queries and concerns that have been raised in this paper. If the Recommendation is to form at least part of the basis for the Commission's next step - its proposal for a new legislative instrument to

\footnotetext{
${ }^{188}$ Current bankruptcy reforms in Italy relating primarily to non-performing loans have not been triggered by the RR, see 'Beautifying Bankruptcy', The Economist, 4 July 2015, pp. 62-63.

${ }^{189} \mathrm{n} 26$ Section 1, noting that reforms in the Netherlands and Sweden may also be forthcoming.

190 ibid Section 4.

191 ibid.
} 
harmonise Member State laws - then the Commission would do well to take these issues seriously. 